\title{
Genetic differences in the aryl hydrocarbon receptor and CYP1A2 affect sensitivity to developmental polychlorinated biphenyl exposure in mice: relevance to studies of human neurological disorders
}

\author{
Kelsey Klinefelter ${ }^{\# 1,2}$, Molly Kromme Hooven ${ }^{\# 1,2}$, Chloe Bates ${ }^{1}$, Breann T. Colter ${ }^{1}$, \\ Alexandra Dailey ${ }^{1}$, Smitha Krishnan Infante ${ }^{1}$, Izabela Kania-Korwel ${ }^{4}$, Hans-Joachim \\ Lehmler $^{4}$, Alejandro López-Juárez ${ }^{3}$, Clare Pickering Ludwig ${ }^{1}$, and Christine Perdan Curran ${ }^{1}$ \\ 1 Department of Biological Sciences, Northern Kentucky University, SC344 Nunn Drive, Highland \\ Heights, KY 41076, USA \\ 2 Division of Developmental Biology, Cincinnati Children's Hospital Medical Center, Cincinnati, $\mathrm{OH}$ \\ 45229, USA \\ 3 Division of Experimental Hematology and Cancer Biology, Cincinnati Children's Hospital \\ Medical Center, Cincinnati, OH 45229, USA \\ ${ }^{4}$ Department of Occupational and Environmental Health, College of Public Health, University of \\ lowa, lowa City, IA 52242, USA \\ \# These authors contributed equally to this work.
}

\begin{abstract}
Polychlorinated biphenyls (PCBs) are persistent organic pollutants that remain a human health concern with newly discovered sources of contamination and ongoing bioaccumulation and biomagnification. Children exposed during early brain development are at highest risk of neurological deficits, but highly exposed adults reportedly have an increased risk of Parkinson's disease. Our previous studies found allelic differences in the aryl hydrocarbon receptor and cytochrome P450 1A2 (CYP1A2) affect sensitivity to developmental PCB exposure, resulting in cognitive deficits and motor dysfunction. High-affinity $A h r^{b} C y p 1 a 2(-/-)$ mice were most sensitive compared with poor-affinity $A h r^{d} C y p 1 a 2(-/-)$ and wild-type $A h r^{b} C y p 1 a 2(+/+)$ mice. Our followup studies assessed biochemical, histological, and gene expression changes to identify the brain regions and pathways affected. We also measured PCB and metabolite levels in tissues to determine if genotype altered toxicokinetics. We found evidence of AHR-mediated toxicity with reduced thymus and spleen weights and significantly reduced thyroxine at P14 in PCB-exposed
\end{abstract}

Christine Perdan Curran, Curranc1@nku.edu.

Compliance with ethical standards

Data availability The datasets for all figures and tables in this article are available from the corresponding author on reasonable request.

Animal welfare All applicable international, national, and/or institutional guidelines for the care and use of animals were followed, and all protocols were approved by the Northern Kentucky University Institutional Animal Care and Use Committee.

Electronic supplementary material The online version of this article (https://doi.org/10.1007/s00335-017-9728-1) contains supplementary material, which is available to authorized users. 
pups. In the brain, the greatest changes were seen in the cerebellum where a foliation defect was over-represented in Cyp1a2(-/-) mice. In contrast, we found no difference in tyrosine hydroxylase immunostaining in the striatum. Gene expression patterns varied across the three genotypes, but there was clear evidence of AHR activation. Distribution of parent PCB congeners also varied by genotype with strikingly high levels of PCB 77 in poor-affinity $A h r^{d} C y p 1 a 2(-/-)$ while $A h^{b}$ Cyp1a2(+/+) mice effectively sequestered coplanar PCBs in the liver. Together, our data suggest that the AHR pathway plays a role in developmental PCB neurotoxicity, but we found little evidence that developmental exposure is a risk factor for Parkinson's disease.

\section{Introduction}

Polychlorinated biphenyls are persistent organic pollutants linked to numerous adverse health effects in humans, including immune suppression, cancer, and neurological deficits (ATSDR 2015). PCBs are also considered endocrine disrupters with reported effects including impaired reproduction and reduction of circulating thyroid hormone levels (UNEP 2001; ATSDR 2015). Despite numerous bans on commercial production (UNEP 2001), PCBs remain ubiquitous in the environment and the food supply (Gomara et al. 2005; Langer et al. 2007; Marek et al. 2017). New PCB sources have recently been identified, including their inadvertent production during the manufacture of paint pigments ( $\mathrm{Hu}$ and Hornbuckle 2010) and the discovery of PCBs in and around many U.S. schools (Marek et al. 2017). Because PCBs are lipophilic and can bioaccumulate and biomagnify, the risk to pregnant women and their offspring is expected to remain high for years to come (Quinn et al. 2011; Bányiová et al. 2017).

The evidence for PCB-induced motor dysfunction comes from both human and animal studies. Stewart et al. (2000), Vreugdenhil et al. (2002), and Boucher et al. (2016) all reported motor deficits in children exposed to PCBs. In the most recent study, mean levels of PCBs in cord blood ranged were $22.4 \mu \mathrm{g} / \mathrm{kg}$ fat for PCB $118,50.2 \mu \mathrm{g} / \mathrm{kg}$ fat for PCB 180 , $81.6 \mu \mathrm{g} / \mathrm{kg}$ fat for PCB 138, and $124.3 \mu \mathrm{g} / \mathrm{kg}$ fat for PCB 153 (Boucher et al. 2016) with levels up to $50 \%$ lower when the children were retested at 11 years of age. All four congeners were associated with decreased fine motor skills, and the strongest association was with blood levels at age 11. Hydroxylated PCB metabolites are also linked with motor dysfunction (Berghuis et al. 2013; Haijima et al. 2017). Animal studies show dopamine depletion after PCB exposure (Seegal et al. 1986, 1994, 1997, 2005) and specificity of cell death in nigrostriatal pathways (Lee et al. 2012), but the evidence for PCBs as a risk factor for Parkinson's disease is mixed. Indeed, an expert panel concluded that there is insufficient evidence to determine if an association exists (Bronstein et al. 2009).

However, PCBs are a diverse group of chemicals with 209 possible congeners and multiple targets in the body. PCBs are well known to lower thyroid hormone levels (Curran et al. 2011a; Giera et al. 2011), and supplemental thyroxine attenuated PCB-induced motor deficits and low-frequency hearing loss (Goldey and Crofton 1998). Interestingly, there is evidence that CYP1A1 can metabolize some PCB congeners into hydroxylated metabolites that disrupt thyroid hormone signaling (Gauger et al. 2007; Wadzinski et al. 2014). Since thyroid hormone is essential for normal cerebellar development (Zoeller and Rovett 2004), it 
is possible that at least some of the observed motor deficits could be caused by cerebellar dysfunction and not deficits in the nigrostriatal pathways affected in Parkinson's disease.

Our previous work demonstrated that allelic differences in the aryl hydrocarbon receptor (AHR) and cytochrome P450 1A2 (CYP1A2) increased sensitivity to developmental PCB neurotoxicity, leading to greater impairments in learning and memory (Curran et al. 2011b, 2012) and in motor function in $A h r^{b} C y p 1 a 2(-/-)$ knockout mice (Stegman et al. 2014; Colter et al. 2017 submitted). The AHR is a ligand-activated transcription factor that binds to coplanar PCBs, dioxins, and polycyclic aromatic hydrocarbons and has been linked to numerous developmental and metabolic pathways, including those in the nervous system (reviewed in Nebert 2017). The AHR regulates the three members of the CYP1 family (CYP1A1, CYP1A2, and CYP1B1), which have orthologs in the mouse. The importance of these genes in metabolism and human disease, particularly cancer, has been widely studied (Nebert and Dalton 2006; Nebert et al. 2013), but less is known about their role in the function and development of the nervous system.

For the AHR, there is similar phenotypic variation between mice and humans in the inducibility of AHR-regulated genes (about 20-fold) and a 60-fold difference in basal CYP1A2 levels in liver (Nebert and Dalton 2006), so our model allows us to examine the role of both genes in PCB developmental neurotoxicity. $A h r^{b}$ mice have high affinity for planar molecules, whereas $A h r^{d}$ mice are considered nonresponders with poor affinity for those ligands (Denison and Faber 2017; Nebert 2017). The focus of this project was to explore mechanisms of neurotoxicity in three genotypes of mice varying at the $A h r$ and $C y p$ loci by examining changes in thyroid hormone signaling and gene expression in brain regions required for normal motor function: the dorsal striatum, cerebellum, and cortex.

\section{Materials and methods}

\section{Animals}

We used C57BL/6J mice (The Jackson Laboratory, Bar Harbor ME) with the $A r^{b}$ Cypla2(+/+) genotype and two lines of knockout mice which have been back-crossed at least 8 generations onto the B6 background: high-affinity $A h r^{b} C y p 1 a 2(-/-)$ and pooraffinity $A h r^{d}$ Cyp1a2(-/-) mice. We did not include $A h r^{d}$ Cyp1a2(+/+)(B6.D2) mice in these studies, because we found minimal effects in our previous gavage dosing studies (Curran et al. 2011a, b). All mice were housed in polysulfone shoebox cages with corncob bedding and one $5 \mathrm{~cm}^{2}$ nestlet provided weekly for enrichment. Food (LabDiet 5015) and water were provided ad libitum with a 12:12-h light-dark cycle under temperature and humiditycontrolled conditions. A maximum of one male and one female per litter was used in each test ( $N \geq 6$ litters per group for all tests).

\section{Breeding}

Nulliparous females between 2.5 and 4 months of age were mated with males of the same genotype in a 4-day breeding cycle. The morning a vaginal plug was found, the female was separated from the male and housed individually for delivery. 


\section{Treatments}

A mixture of PCBs was developed (Curran et al. 2011a) using congeners reported most commonly in the human food supply and in human samples (van den Berg et al. 2006; Costabeber et al. 2006; Langer et al. 2007). These were coplanar PCBs 77, 126, and 169 and non-coplanar PCBs 105, 118, 138, 153, and 180 (ULTRA Scientific, North Kingstown RI) dissolved in corn oil (Kroger). The coplanar PCB concentration insured persistent AHR activation through weaning in the high-affinity $A h r^{b}$ mice, but not in poor-affinity $A h r^{d}$ mice (Colter et al. 2017 submitted). We used a mixture to better model human exposures because single congeners do not produce the same effects seen in human cohorts (Ulbrich and Stahlmann 2004). Pregnant dams were dosed daily with $\sim \sum 5.6 \mathrm{mg} / \mathrm{kg}$ PCBs by providing a small piece of Froot Loop ${ }^{\circledR}$ cereal containing the PCB solution or an equivalent volume of corn oil for control animals. Additional information regarding the dosing solution is provided as Supplemental Material (Table S1). Dosing began the afternoon of the day a vaginal plug was found and continued through weaning at postnatal day 25 (P25) with animals randomly assigned to each group.

\section{Tissues}

To avoid confounding by circadian rhythms, all tissues for PCB quantification and qPCR were collected during the same 3-h time period (15:00-18:00 h) at P14, P25, P30, and P120. Blood was collected by cardiac puncture for PCB quantification. Trunk blood was collected for thyroid hormone measurements, centrifuged at $1500 \mathrm{~g}$ for $5 \mathrm{~min}$ at $4{ }^{\circ} \mathrm{C}$, and the plasma fraction stored at $-80^{\circ} \mathrm{C}$ until analysis. Liver, inguinal fat pad, cerebellum, and cortex were harvested, snap frozen, and stored at $-80{ }^{\circ} \mathrm{C}$ until analysis. Spleen and thymus were dissected out in P14 mice and wet weights recorded.

\section{Thyroid hormone measurements}

We measured total thyroxine (T4) levels at P14 and in P120 littermates used in motor function test using a standard ELISA kit (Alpco Diagnostics, Salem $\mathrm{NH}$ ) following the manufacturer's protocol. The limit of detection was $0.5 \mu \mathrm{g} / \mathrm{dl}$ with samples diluted to concentrations that fell within a standard curve from 0 to $25 \mu \mathrm{g} / \mathrm{dl}$. The coefficient of variation was $4.9 \%$ for intra-assay precision and $5.7 \%$ for interassay variability.

\section{Tissue processing for immunohistochemistry}

Mice were euthanized with $\mathrm{CO}_{2}$ and perfused transcardially with $1 \times$ PBS followed by $4 \%$ paraformaldehyde in phosphate buffer. Brains were removed and cryoprotected in 30\% sucrose in $0.1 \mathrm{M}$ PBS for coronal sectioning on a cryostat ( $40 \mu \mathrm{m}$, striatum) or sagittal sectioning on a vibratome ( $30 \mu \mathrm{m}$, cerebellum). Brains were collected at P25 and at P120 from littermates used for motor function testing. P25 brains were used for cerebellar immunohistochemistry. P120 brains were used for tyrosine hydroxylase immunostaining.

\section{Immunohistochemistry for tyrosine hydroxylase in striatum at P120}

Six striatal sections per animal were selected for immunohistochemistry. To enhance antigen retrieval, we soaked tissue in sodium citrate buffer at $80{ }^{\circ} \mathrm{C}$ for $30 \mathrm{~min}$ followed by washes in $0.1 \mathrm{M}$ PBS. Next, tissues were incubated in $0.3 \% \mathrm{H}_{2} \mathrm{O}_{2}$ (Sigma) in $0.1 \mathrm{M}$ PBS for $30 \mathrm{~min}$ 
at room temperature with shaking. The solution was replaced with normal goat serum/Triton $100 \times$ blocking solution and incubated for $2 \mathrm{~h}$ at room temperature with shaking. The tissue was then incubated in the primary antibody (Abcam Cat\# ab112, RRID:AB_297840) at a 1:5000 dilution in blocking solution at $4{ }^{\circ} \mathrm{C}$ for $48 \mathrm{~h}$ with shaking. After washes to remove the primary antibody, the sections were incubated for $2 \mathrm{~h}$ in the secondary antibody (antirabbit IgG biotinylated antibody from Vector ABC Elite kit) at room temperature with shaking. The sections were then incubated in HRP-ABC complex (Vector ABC Elite) for $1 \mathrm{~h}$ at room temperature with shaking followed by staining with diaminobenzidine (Vector DAB kit) and incubation for $10 \mathrm{~min}$ at room temperature. Following a final 15-min rinse sequence with $0.1 \mathrm{M}$ PBS, the sections were stored in $0.1 \mathrm{M}$ PBS with $0.05 \%$ sodium azide until mounting.

\section{Optical density analysis}

Slides were viewed on an Olympus microscope with a Motic camera attachment at $10 \times$ magnification and associated software (Version 2.0). Slides were photographed in grayscale for importing into ImageJ. All images were calibrated using the standard ImageJ step tablet to ensure uniformity. Background was subtracted using the rolling ball radius function. A grid was overlaid on the image and the line closest to the center of the striatum as possible was selected. This area was divided evenly into left and right dorsal and ventral quadrants. We used a random number generator to select six squares from each hemisphere for analysis (Fig. 1). The optical density of each square was measured, and the mean O.D. for each hemisphere was calculated for statistical analysis following the methods of (GonzálezFranco et al. 2017).

\section{Immunohistochemistry and image analysis of cerebellum at P25}

Vibratome floating sections were blocked in PBS 1X/Triton $100 \times 0.3 \% / F B S$ and processed for immunodetection of proteins using specific antibodies for GFAP (Sigma-Aldrich; G-3893), Blbp (Millipore; ABN14) parvalbumin (Millipore; AB15738), calbindin (SigmaAldrich; C8666), and NeuN (Millipore; MAB377). The appropriate fluorophore-conjugated secondary antibodies (Alexa 488, Alexa 568, Alexa 647; Invitrogen) were used to detect the antigen-antibody complexes. To corroborate the specificity of the primary antibodies of markers of cerebellar cell types, incubation with only secondary antibody and DAPI was also performed. Marker-positive cells matched the morphology of the cerebellar cell type anticipated while no other DAPI positive showed signal, and no signals were found in only secondary antibody-stained tissues. Sections were mounted on slides using Fluoromount G (Thermo Fisher). Using the appropriate laser excitation wavelength (405, 488 or $561 \mathrm{~nm}$ ), images were captured on a Nikon C2 confocal microscope. Image J (NIH) software was used to calculate the perimeter and area of the granule cell layer and to compare the number of Purkinje cells across different folia. Images were assessed by investigators blinded to genotype and treatment groups.

\section{Real-time quantitative PCR arrays}

Snap-frozen tissues were homogenized in RNAzol (Molecular Research Center, Cincinnati, $\mathrm{OH}$ ) with 50-100 mg tissue per ml RNAzol using a Dounce homogenizer for cortex and cerebellum. RNA was extracted using the manufacturer's protocol, and the RNA pellets 
were re-suspended in $50 \mu \mathrm{l}$ of nuclease-free water for brain and in $75 \mu \mathrm{l}$ for liver. RNA concentration was quantified on a Nanodrop (Thermo Fisher), and 500 ng total RNA was used for the cDNA reaction using the $\mathrm{RT}^{2}$ First Strand Kit (Qiagen).

The cDNA was analyzed using an R $\mathrm{T}^{2}$ Custom PCR Array (Qiagen) with primers for 39 candidate genes, 5 housekeeping genes, and negative and positive controls. Genes were selected after a literature search for genes related to activation of the aryl hydrocarbon receptor, cerebellar development, oxidative stress, neuroinflammation, and other pathways implicated in PCB toxicity and endocrine disruption (ryanodine receptor/calcium homeostasis, oxidative stress, estrogen, and thyroid hormone pathways). Two samples were run on each 96-well plate in an Applied Biosystems 7300 Real-time PCR system using the following program: $10 \mathrm{~min}$ at $95^{\circ} \mathrm{C}, 40$ cycles of $15 \mathrm{~s}$ at $95{ }^{\circ} \mathrm{C}$ followed by $1 \mathrm{~min}$ at $60{ }^{\circ} \mathrm{C}$. The RT ${ }^{2}$ PCR Array Data Analysis version 3.5 was utilized to compare fold-change in three genotypes of PCB-treated mice with corn oil-treated wild-type mice using the Delta-Delta Ct method.

\section{Chemicals for PCB quantification}

Analytical standards of 2,3,5,6-tetrachlorobiphenyl (PCB 65, 99.4\%); 2,3,3',4,4' pentachlorobiphenyl (PCB 105, > 99.9\%); 2,2' 3,4,4' , $5^{\prime}$-hexachlorobiphenyl (PCB 138, >

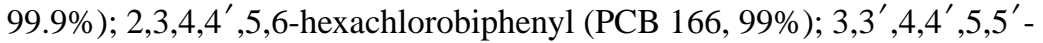

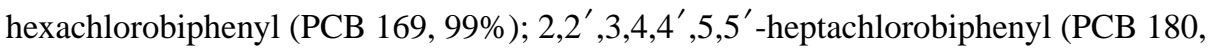
99.2\%), 2,2 $2^{\prime}, 3,4,4^{\prime}, 5,6,6^{\prime}$-octachlorobiphenyl (PCB 204, 99.9\%), and $2^{\prime}, 3,3^{\prime}, 4^{\prime}, 5,5^{\prime}$ hexachlorobiphenyl-4-ol (4-159, > 99.9\%) were purchased from AccuStandard (New Haven, CT). Standards of 3,3' $3^{\prime}, 4^{\prime}$-tetrachlorobiphenyl (PCB 77); 2,3' $3^{\prime}, 4,4^{\prime}, 5-$ pentachlorobiphenyl (PCB 118); 3, $3^{\prime}, 4,4^{\prime}, 5$-pentachlorobiphenyl (PCB 126), and 2,2' $2^{\prime} 4,4^{\prime}$, $5,5^{\prime}$-hexachlorobiphenyl (PCB 153) were synthesized as described previously (KaniaKorwel et al. 2004; Lehmler and Robertson 2001; Schramm et al. 1985). Methylated standards of OHPCBs, including 2,3,3', $4^{\prime}, 5$-pentachloro-4-methoxybiphenyl (4-107, > $98 \%) ;, 2,2^{\prime}, 3^{\prime}, 4,4^{\prime}$ 5-hexachloro-3-methoxybiphenyl ( $\left.3^{\prime}-138,>98 \%\right), 2,2^{\prime}, 3,4^{\prime}, 5,5^{\prime}$ -

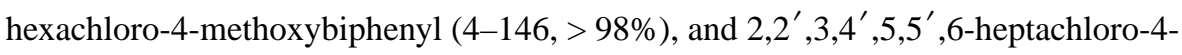
methoxybiphenyl (4-187, > 98\%) were purchased from Wellington Laboratories (Guelph, ON), Canada. Hydroxylated metabolite standards of PCB 77, including $3,3^{\prime}, 4^{\prime}, 5-$ tetrachlorobiphenyl-4-ol (4'-79); $3^{\prime}, 4,4^{\prime}, 5$-tetrachlorobiphenyl3-ol (5-77) and $3^{\prime}, 4,4^{\prime}, 5$ tetrachlorobiphenyl-2-ol (6-77) were prepared as described previously (van den Hurk et al. 2002). Standards synthesized in our laboratory were $>99 \%$ pure by GC analysis. The nomenclature of metabolites follows an abbreviated nomenclature proposed by Maervoet et al. (2004).

\section{Extraction of tissues}

Adipose (0.0606-0.3107 g), blood (0.2446-0.5884 g), cerebellum (0.0319-0.0573 g), cortex $(0.1215-0.2468 \mathrm{~g})$, and liver samples $(0.2402-0.2468 \mathrm{~g})$ were spiked with surrogate standards (PCBs 65 and 166, 4-159) and extracted with hexane-acetone (1:1 v/v) using an Accelerated Solvent Extractor (Dionex, Sunnyvale, CA) as described previously (KaniaKorwel et al. 2007). Sample blanks containing only Florisil and diatomaceous earth as well as an ongoing precision and recovery (OPR) standard (i.e., sample blanks spiked with all 
analytes) were extracted in parallel with each set of samples. Extracts were concentrated and derivatized with diazomethane to transform $\mathrm{OH}-\mathrm{PCB}$ into methoxylated compounds for gas chromatographic analysis (Kania-Korwel et al. 2008). Afterwards, samples underwent sulfur clean-up, followed by sulfuric acid treatment as reported previously (Kania-Korwel et al. 2005).

\section{Gas chromatography analysis}

Levels of PCBs and OH-PCB metabolites in each extract were quantified using an Agilent $6890 \mathrm{~N}$ or Agilent 7890A gas chromatograph equipped with a SPB-1 column $60 \mathrm{~m}$ length, $0.25 \mathrm{~mm}$ inner diameter, $0.25 \mu \mathrm{m}$ film thickness; (Supelco, St. Louis, MO) and a ${ }^{63} \mathrm{Ni} \mu$ electron capture detector. The injector and detector temperatures were 280 and $300{ }^{\circ} \mathrm{C}$, respectively. The following temperature program was used: $80^{\circ} \mathrm{C}$ for $1 \mathrm{~min}, 15^{\circ} \mathrm{C} / \mathrm{min}$ increase to $260{ }^{\circ} \mathrm{C}, 1{ }^{\circ} \mathrm{C} / \mathrm{min}$ increase to $274{ }^{\circ} \mathrm{C}$, and $15^{\circ} \mathrm{C} / \mathrm{min}$ increase to $300^{\circ} \mathrm{C}$. PCBs $105+153$ and 5-77 + 4-107 co-eluted on the SPB-1 column and are reported as sum of both co-eluting compounds. PCB and OH-PCB levels were calculated using PCB 204 as volume corrector and adjusted for tissue wet weights. The instrument and method detection limits for target analytes are summarized in Supplemental Material (Table S2).

\section{Quality assurance/quality control}

The detector response was linear $\left(\mathrm{R}^{2}>0.99\right)$ in the range from 1 to $500 \mathrm{ng}$ for all analytes $\left(\mathrm{R}^{2}>0.99\right)$. The recoveries of the surrogate standards PCB 65, PCB 166, and 4-159 were 88 $\pm 11 \%$ (range 53-112), $94 \pm 13 \%$ (range 55-129), and $80 \pm 18 \%$ (range 29-114), respectively. The concentrations of target analytes were corrected by the recoveries of the surrogate standards added to each sample. The recoveries from the OPR standard analyzed in parallel with each sample set ranged from 78 to $112 \%$.

\section{Statistical analysis}

Data were analyzed using SAS Proc Mixed Models Analysis of Variance with litter as the unit of analysis. When differences were found, we examined slice effects with a correction for multiple post hoc analyses. For statistical analyses of PCB congeners and metabolites, values were set to the Limit of Detection for samples shown as Not Detected (ND). To compare the frequency of the cerebellar foliation deficit, we used a Chi-Square analysis. Data are presented as least square means \pm the standard error of the mean (SEM). For all analyses $P<0.05$ was considered significant.

\section{Results}

\section{Spleen and thymus weights}

There was a main effect of PCB treatment and a significant gene $\times$ treatment interaction with PCB-treated P14 pups having significantly lower spleen $(P<0.01)$ and thymus $(P<0.001)$ wet weights. The greatest reductions were seen in PCB-treated $A h r^{b} C y p 1 a 2(-/-)$ knockout mice (Fig. 2a-d). 


\section{Thyroid hormone levels}

Total plasma thyroxine (T4) was significantly lower at P14 in all three genotypes of mice exposed to PCBs during gestation and lactation $(P<0.001)$; however, T4 levels returned to normal in adult mice where there were no significant differences (Fig. 3a-c).

\section{Optical density measurements of striatum at P120}

We compared tyrosine hydroxylase staining in the striatum of PCB-treated mice from all three genotypes to values from corn oil-treated control B6 mice. There were no significant differences in tyrosine hydroxylase staining across these four groups (Fig. 4).

\section{Histology of cerebellum at P25}

Decreased levels of thyroxine in PCB-treated mice (Fig. 3a-c) may affect biological processes where thyroid hormone is requested, such as cerebellum development. To test this possibility, we analyzed cerebellar structure and cellular composition in vehicle- and PCBtreated mice. We found no significant differences in the total area of the cerebellum at the level of the vermis, the area of the granule cell layer, the number of Purkinje cells, or the perimeter of the Purkinje cell layer in PCB-treated mice compared with their respective corn oil-treated controls (data not shown).

\section{Cerebellar foliation defect at P25}

A comparison of sagittal sections from control B6 mice and PCB-treated knockout mice revealed a foliation defect involving folia VIII and IX (Fig. 5a, b). This observation was followed up with a detailed analysis of cerebellar sections from all groups. We observed abnormal foliation patterns at a significantly higher frequency in PCB-treated mice ( $P<$ 0.01 ) with the highest percentage (67\%) in PCB-treated $A h_{r}{ }^{b} C y p 1 a 2(-/-)$ mice followed by $50 \%$ of PCB-treated $A h r^{d}$ Cyp 1 a2(-/-) mice. In contrast, only $18 \%$ of corn oil-treated control mice showed the defect. In addition to aberrant lamination, we also detected invasion of Bergmann glial cells into the granule cell layer of PCB-treated knockout mice (Fig. 6a-f). These results suggest late cerebellar developmental defects in response to PCBs.

\section{Gene expression differences in cerebellum and cortex}

Based on the histology and immunohistochemistry results, we focused our gene expression studies on the cerebellum and the cortex, because both play a role in regulating motor function and motor memory. All changes in gene expression were compared with corn oiltreated control mice of the $A h_{r}{ }^{b} \mathrm{Cyp} 1 \mathrm{a} 2(+/+)$ genotype (i.e., the C57BL/6J strain). Details of fold-changes and $P$ values can be found in Tables 1, 2, and 3 .

\section{Differences at P14 in cerebellum}

We found only three significant differences in PCB-treated $A h r^{b}$ Cypla2(+/+). Expression of the aryl hydrocarbon receptor and fibroblast growth factor- 2 were modestly upregulated, whereas expression of estrogen receptor alpha was more than doubled. Only $A h r^{b} C y p 1 a 2(-/$ -) mice showed clear evidence of AHR activation with increases in both the aryl hydrocarbon receptor repressor (1.88 fold increase) and CYP1A1 (2.01 increase), although the increase in CYP1A1 was not statistically significant. There was a significant down- 
regulation of retinoid-related orphan receptor alpha (Rora), neurotrophin-3 (Ntf-3), and glutamate-cysteine ligase modifier $(\mathrm{Gclm})$. Gene expression in poor-affinity $\mathrm{Ahr}^{\mathrm{d}} \mathrm{Cyp} 1 \mathrm{a2}(-/$ -) mice had some similarities to wild-type mice with significant increases in fibroblast growth factor-2 and estrogen receptor alpha. There were also significant increases in insulinlike growth factor- 1 and ryanodine receptor- 3 . The greatest change was a more than sixfold decrease in expression of Purkinje cell protein-2 (Pcp2); however, the differences did not reach statistical significance $(P=0.09)$.

\section{Differences at P30 in cerebellum}

Unexpectedly, all three lines of mice showed evidence of AHR activation in the cerebellum at P30, but the patterns of gene expression differed based on Cyp1a2 genotype. CYP1B1 was significantly upregulated in $A h r^{b} C y p 1 a 2(+/+)$ mice, whereas the AHR was downregulated and CYP1A1 was upregulated in both $A h r^{b} C y p 1 a 2(-/-)$ and $A h r^{d} C y p 1 a 2(-/-)$ mice. We also found some evidence of compensatory processes with upregulation of both NMDA receptor subtype-2A (Grin2a) and nerve growth factor only in wild-type $A h r^{b}$ Cypla2(+/+) mice, but the differences did not reach statistical significance $(P=0.06$ and $P=0.09$, respectively).

\section{Differences at P14 in cortex}

The pattern of gene expression in cortex was much different. Nerve growth factor was significantly down-regulated in high-affinity $A h r^{b} C y p 1 a 2(+/+)$ and poor-affinity $A h r^{d}$ Cyp1a2(-/-) mice. Similar to P14, estrogen receptor alpha was also significantly upregulated in $A h_{r}{ }^{d}$ Cyp1a2(-/-) mice. The most pronounced differences were in highaffinity $A h r^{b} C y p 1 a 2(-/-)$ mice with clear evidence of AHR activation by significant upregulation of both CYP1A1 and CYP1B1. There was also significant down-regulation of myelin basic protein, Grin2a, prostaglandin G/H synthase-2 (Ptgs2), and paraoxonase-2 (Pon2).

\section{Tissue levels of PCB and hydroxylated metabolites}

To determine if differential toxicokinetics could partially explain differences in gene expression, we compared levels of the parent PCB congeners in cerebellum, cortex, liver, adipose, and blood (Table 4) and hydroxylated metabolites in blood and liver (Table 5). We found strikingly high levels of coplanar PCB 77 in adipose, liver, and blood of poor-affinity $A h r^{d}$ Cypla2(-/-) mice and also significantly higher levels in cerebellum with no difference in cortex. Levels of coplanar PCB 126 were significantly higher in the liver of high-affinity $A h r^{b}$ Cypla2(+/+) mice. Levels of coplanar PCB 169 were also higher in this line, although the differences did not reach statistical significance. In contrast, PCB 126 levels were significantly higher in the blood and adipose of the two Cypla2(-/-) knockout lines of mice.

When comparing levels of non-coplanar PCB congeners, we found significantly higher levels of PCB105 + PCB153 in the blood and cerebellum of $A h r^{b}$ Cyp1a2(-/-) mice and significantly higher levels in the liver and adipose of both Cyp1a2(-/-) knockout lines. Levels of PCB 118 were significantly higher in the cerebellum of $A h r^{b}$ Cypla2(-/-) mice and significantly higher in the blood of both Cypla2(-/-) knockout lines. Levels of PCB 138 were significantly higher in the cerebellum of $A h r^{b} C y p 1 a 2(-/-)$ mice with no 
significant differences in other tissues. Levels of PCB 180 were significantly higher in the cerebellum, blood, and liver of $A h r^{b} C y p 1 a 2(-/-)$ mice with no differences in cortex and adipose.

\section{Discussion}

Although the neurotoxicity of PCBs has been well established (Jacobson and Jacobson 1997, 2003; Schantz et al. 2003; Ross 2004), less is known about the cause of motor deficits following $\mathrm{PCB}$ exposure, and there is minimal data concerning gene-environment interactions following PCB exposure. Of specific concern to human health is the possibility that PCBs may be a risk factor for Parkinson's disease (Steenland et al. 2006; Caudle et al. 2006) and reports of motor deficits in children exposed during early brain development (Stewart et al. 2000; Vreugdenhil et al. 2002; Wilhelm et al. 2008). Because human body burdens are expected to remain high for several generations (Quinn et al. 2011), understanding gene-environment interactions will be important in identifying and protecting the most vulnerable human populations from PCB-induced motor dysfunction.

Our prior work looking at developmental PCB neurotoxicity in mice revealed that allelic differences in both the aryl hydrocarbon receptor and CYP1A2 exacerbated PCB-induced learning and memory deficits (Curran et al. 2011b, 2012). We have now extended those studies to PCB-induced motor dysfunction and found a similar role for the AHR and CYP1A2 (Stegman et al. 2014; Colter et al. 2017 submitted). The studies reported here were designed to identify the specific brain regions affected and the critical pathways involved in motor dysfunction. By assessing multiple endpoints, we were able to address three important questions: What is the evidence that PCBs are a risk factor for Parkinson's disease? Could motor deficits be explained instead by thyroid hormone depletion and cerebellar dysfunction? Is there cross-talk between AHR-mediated pathways and other pathways involved in PCB neurotoxicity?

The evidence for PCBs as a risk factor for Parkinson's disease (PD) remains mixed. Hatcher-Martin et al. (2012) reported higher levels of PCB 138, 153, and 180 in the postmortem brains of female Parkinson's patients compared with male PD patients and control brains. Steenland et al. (2006) reported a higher risk of Parkinson's disease in women with high occupational exposure at upstate New York capacitor factories, and Seegal et al. (2010) reported that higher PCB serum levels were correlated with lower dopamine transporter densities only in female workers from that same cohort. However, a more recent analysis combining three industrial cohorts found no association between PD and PCB exposure (Ruder et al. 2014), and a case-control study in Finland turned up an inverse relationship with lower risk in the most highly exposed quintile (Weisskopf et al. 2012). Petersen et al. (2008) reported a higher risk of PD in adults with high consumption of contaminated whale meat and blubber. This raises the question about the route of exposure, since the occupational cohorts had exposures 10- to 50-fold higher than the general population compared with two- to sixfold higher in the Inuit and Faroe Island populations (Goldman 2014). Our data from mice exposed during gestation and lactation do not support developmental PCB exposure as a risk factor, but we must emphasize the mice were only aged to P120. 
Thymic involution and reduced spleen weights are well-recognized evidence of AHRmediated developmental toxicity, which can be easily assessed in neonates (Lin et al. 2001; Curran et al. 2006, 2011a). We found strong evidence of AHR-mediated toxicity in the highaffinity $A h r^{b} C y p 1 a 2(-/-)$ mouse line (Fig. 2a-d). We also found significant upregulation of AHR target genes in this mouse line in both cerebellum and cortex (Tables 1,2,3) with more modest changes in AHR-regulated genes in the other lines of mice. Together, these findings support prior studies that maternal CYP1A2 is protective against AHR-mediated toxicity (Diliberto et al. 1997; Dragin et al. 2006; Curran et al. 2011a, b) and that highaffinity $A h r^{b}$ mice are more sensitive to developmental PCB exposure than poor-affinity $A h r^{d}$ mice (Curran et al. 2006, 2011a, b).

We compared thyroid hormone levels at P14 and at 4 months of age (Fig. 3a-c). Our findings were consistent with previous reports showing reduction of circulating thyroid hormone in neonatal mice (Bansal and Zoeller 2008; Darras 2008; Curran et al. 2011b), but we found no difference in T4 levels in adult mice. The lowest levels of T4 were found in PCB-treated $A h r^{b} C y p 1 a 2(-/-)$ mice, again suggesting a role for the AHR and CYP1A2 in PCB toxicity. In addition to previously described changes in AHR-regulated genes, the greatest changes seen in our qPCR arrays were in genes involved in thyroid hormone pathways. PCB-treated $A h r^{b}$ Cypla2(-/-) mice had decreased expression of Rora, which normally enhances thyroid hormone signaling (Qiu et al. 2009) and is mutated in the staggerer mouse resulting abnormal cerebellar development (Hamilton et al. 1996). PCBtreated $A h r^{b}$ Cyp1a2(-/-) mice also had significantly decreased levels of neurotrophin-3 (Ntf-3) at P14. Our findings are consistent with those of Koibuchi et al. (2001) who reported decreased expression of Ntf-3 and Rora in hypothyroid neonatal mice.

We also found differences in the expression of $F g f 2, M b p, N g f$, and Pcp2, which are all regulated, at least in part, by thyroid hormone (Koibuchi and Chin 2000, Takahashi et al. 2008). Interestingly, the direction of change varied across genotypes and brain regions. Upregulation of $\mathrm{Fgf2}$ and estrogen receptor alpha in wild-type $A h r^{b} \mathrm{Cyp} 1 \mathrm{a2}(+/+)$ and pooraffinity AhrdCyp1a2(-/-) mice could indicate some compensatory mechanism in response to PCB exposure while the sixfold down-regulation of Pcp2 in AhrdCyp1a2(-/-) mice indicates a unique mode of action for PCB toxicity in that line. This suggests that perinatal exposure to PCB in specific genetic backgrounds can affect brain development, especially in regions of late development, such as the cerebellum. The cerebellum controls fine motor behavior in correlation with the foliation pattern, thus exploring a direct link between the upregulated/down-regulated genes (Tables 1,2) and the folia defects is worthy of future studies.

Hydroxylated PCB metabolites appear most important in causing abnormal cerebellar development (Giera et al. 2011; Takeuchi et al. 2011; Berghuis et al. 2013), and there is evidence that CYP1A1 can metabolize non-coplanar PCBs (Gauger et al. 2007) altering the expression of thyroid hormone-regulated genes during human fetal development (Wadzinski et al. 2014). Koh et al. (2016) recently reported finding hydroxylated PCB metabolites in $60 \%$ of human sera samples, so we also examined PCB distribution and metabolism in weanling pups. 
We found significant differences across genotypes with poor-affinity AhrdCyp1a2(-/-) mice showing strikingly high levels of coplanar PCB 77 in adipose, liver, and cerebellum. This was consistent with our previous findings in gavage-treated animals (Curran et al. 2011a). Wild-type $A t^{b}{ }^{b}$ ypla2(+/+) mice had significantly higher levels of coplanar PCB 126 in liver, whereas both Cyp1a2(-/-) lines of mice had higher levels in adipose (Table 4). This is also consistent with our previous findings and evidence of coplanar PCB sequestration by maternal CYP1A2. However, there were no significant differences in the levels of hydroxylated PCB metabolites (Table 5). Since our previous work demonstrated differences in parent congener levels throughout gestation and lactation, it will be important to extend these studies to other development time points and to assess both parent congeners and hydroxylated PCB metabolites as well as gene expression. This future work would also help to clarify if prenatal or postnatal exposures have similar or differing effects.

The blood PCB levels were several orders of magnitude higher compared to PCB levels reported in recent biomonitoring studies. For example, a small group of teachers $(N=18)$ had levels of PCB 118 of $80 \mathrm{pg} / \mathrm{g}$ serum, whereas levels in our study were 75,000 pg/g whole blood (Table 4) (Herrick et al. 2011). According to NHANES 2003-2004 data, PCB 118 levels in the general U.S. population were $31 \mathrm{pg} / \mathrm{g}$ serum and $59 \mathrm{pg} / \mathrm{g}$ serum for individuals $<50$ and $>50$ years of age, respectively (Herrick et al. 2011). Historical levels before PCB production ceased were considerably higher. Weisskopf et al. (2012) reported levels as high as $82.1 \mathrm{ng} / \mathrm{g}$ serum in human samples collected from 1968 to 1972 in Finland. Occupational cohorts had levels 10- to 50-fold higher than the general population (Goldman 2014). In this study, OH-PCB levels in whole blood from mice were ranged from not detected to $170 \mathrm{ng} / \mathrm{g}$ whole blood (Table 5). In a highly PCB-exposed Inuit population, the sum of total OH-PCBs ( $\Sigma \mathrm{OH}-\mathrm{PCBs}$ ) ranged from 0.16 to $10.1 \mathrm{ng} / \mathrm{g}$ whole blood in men $(N=$ 13 ) and 0.12 to $11.6 \mathrm{ng} / \mathrm{g}$ whole blood in women $(N=17)$ (Sandau et al. 2000). Several other studies report lower $\Sigma$ OH-PCBs levels in serum or plasma (typically $<1 \mathrm{ng} / \mathrm{g}$ ) than those observed in our animal study (for examples, see Hovander et al. 2006; Marek et al. 2014). It is important to emphasize that the PCB doses used in the current study were selected following the fundamental risk assessment principle that higher doses of a toxicant are needed to observe toxicity in the short timeframe of a typical animal study (Doull 2003) and at the low end of exposures used in rodent studies of PCB neurotoxicity (Lein et al. 2007; Lee et al. 2012).

Inducibility of AHR-regulated genes and basal, hepatic CYP1A2 levels are highly variable in the human population (Nebert and Dalton 2006), so it is plausible that genetic differences play a role in human PCB toxicity as well. For example, offspring of mothers with high levels of hepatic CYP1A2 might have lower exposure through gestation and lactation compared with offspring of mothers with low CYP1A2 expression despite similar dietary intake. There are tests available which can provide information concerning an individual's CYP1A2 (Lambert et al. 2006) and AHR metabolic phenotype (Vanden Heuvel et al. 1993, Lin et al. 2003), so our mouse studies suggest possible future human studies focused on populations where there is high dietary intake of PCB-contaminated foods such as the Inuit in Canada and Greenland and Faroe Islanders. 
Our histological analysis and immunohistochemistry experiments focused on effects in the cerebellum and striatum to determine which region was most affected by developmental PCB exposure. We found no differences in the area and perimeter of the cerebellum or granule cell layer and no difference in Purkinje cell numbers. However, we discovered a foliation defect between folia VIII and IX that was significantly more prevalent in PCBtreated Cyp1a2(-/-) mice (Fig. 6a-f). This was a novel finding for PCB-treated mice, although the defect has been reported in the background B6 strain previously (Van Dine et al. 2015). Still, Fauquier et al. (2014) clearly identified Begmann glia and Purkinje cells as targets of thyroid hormone receptor alpha during postnatal cerebellum development. Disruption is normal signaling resulted in abnormal granule cell migration and differentiation. In contrast, we found no differences in tyrosine hydroxylase staining in the striatum indicating no substantial changes in nigrostriatal dopaminergic pathways. Together, these data suggest that the primary target of PCB-induced motor dysfunction is the developing cerebellum and that the mechanism of toxicity is linked to disruptions in normal thyroid hormone signaling. In fact, motor dysfunction has been previously associated with defects in the development of folias VIII-IX of the cerebellum (López-Juárez et al. 2011).

We found no evidence of oxidative stress or neuroinflammation at the time points tested and no evidence that genes important to calcium homeostasis were changed. There was a significant, but modest 1.27-fold increase in expression of ryanodine receptor-3 in the cerebellum of $A h r^{d}$ Cypla2(-/-) mice at P14. The functional significance of that change is uncertain, but the findings are worth further exploration since the ryanodine receptor is strongly linked to PCB neurotoxicity (Pessah et al. 2010).

\section{Conclusions}

While all mouse lines experienced some level of PCB developmental toxicity, high-affinity $A h r^{b}$ Cyp1a2(-/-) mice showed the highest levels of toxicity and greatest changes in gene expression in the brain. Both lines Cyp1a2(-/-) mice had a higher prevalence of a previously unreported cerebellar foliation defect. There were significant differences in PCB distribution and metabolism as well in the three genotypes of mice. Together, these data implicate both the AHR and CYP1A2 in developmental PCB neurotoxicity. We found multiple lines of evidence converging on the cerebellum as the primary target organ for PCB-induced motor deficits with disruption of normal thyroid hormone signaling the most likely mode of action. There was minimal evidence that developmental PCB exposure is a risk factor for Parkinson's disease. However, this does not rule out the possibility of neurotoxicity in adults exposed over a longer period of time or to higher doses from occupational exposures.

\section{Supplementary Material}

Refer to Web version on PubMed Central for supplementary material.

\section{Acknowledgements}

This work was supported by the National Institutes of Health (R15ES020053, P20 GM103436, ES05605, and ES013661), the National Science Foundation (RSF-034-07, DUE-STEP-096928), and the following grants from 
Northern Kentucky University: Faculty Development Project Grants, College of Arts \& Sciences Collaborative Faculty-Student Award, Center for Integrative Natural Science and Mathematics Research Grants, and Dorothy Westerman Herrmann funds. We thank Joshua Lambert, University of Kentucky Department of Statistics, Jiaying Weng and Ya Qi, University of Kentucky Department of Statistics Applied Statistics Laboratory, for assistance with data analysis, and we acknowledge the generous donation of Cyp1a2(-/-) knockout mice from Dr. Daniel W. Nebert, University of Cincinnati Department of Environmental Health. We thank the reviewers for their valuable suggestions and careful review of the manuscript.

\section{References}

Agency for Toxic Substances and Disease Registry (ATSDR) (2015). 2015 CERCLA National priorities list of hazardous substances. U.S. Department of Health and Human Services, Public Health Service Atlanta https://www.atsdr.cdc.gov/spl/

Bansal R, Zoeller RT (2008) Polychlorinated biphenyls (Aroclor 1254) do not uniformly produce agonist actions on thyroid hormone responses in the developing rat brain. Endocrinology 149(8): 4001-4008 [PubMed: 18420739]

Bányiová K, Černá M, Mikeš O, Komprdová K, Sharma A, Gyalpo T, Čupr P, Scheringer M (2017) Long-term time trends in human intake of POPs in the Czech Republic indicate a need for continuous monitoring. Environ Int 108:1-10 [PubMed: 28772152]

Berghuis SA, Soechitram SD, Hitzert MM, Sauer PJJ, Bos AF (2013) Prenatal exposure to polychlorinated biphenyls and their hydroxylated metabolites is associated with motor development of three-month-old infants. NeuroToxicol 38:124-130

Boucher O, Muckle G, Ayotte P, Dewailly E, Jacobson SW, Jacobson JL. (2016). Altered fine motor function at school age in Inuit children exposed to PCBs, methylmercury, and lead. Environ Int 95:144-151 [PubMed: 27575364]

Bronstein J, Carvey P, Chen H, Cory-Slechta D, DiMonte D, Duda J, English P, Goldman S, Grate S, Hansen J, Hoppin J, Jewell S, Kamel F, Koroshetz W, Langston JW, Logroscino G, Nelson L, Ravina B, Rocca W, Ross GW, Schettler T, Schwarzschild M, Scott B, Seegal R, Singleton A, Steenland K, Tanner CM, Van Den Eeden S, Weisskopf M (2009) Meeting report: consensus statement-Parkinson's disease and the environment: collaborative on health and the environment and Parkinson's Action Network (CHE PAN) conference 26-28 June 2007. Environ Health Perspect 117(1):117-121 [PubMed: 19165397]

Caudle WM, Richardson JR, Delea KC, Guillot TS, Wang M, Pennell KD, Miller GW (2006) Polychlorinated biphenyl-induced reduction of dopamine transporter expression as a precursor to Parkinson's disease-associated dopamine toxicity. Toxicol Sci 92:490-499 [PubMed: 16702228]

Colter BT, Garber HF, Fleming SM, Fowler JP, Harding GD, Hooven MK, Howes AA, Infante SK, Lang AL, MacDougall MC, Stegman M, Taylor K, Curran CP (2017) Ahr and Cypla2 genotypes both affect susceptibility to motor deficits following gestational and lactational exposure to polychlorinated biphenyls. Neuro-Toxicology (submitted)

Costabeber I, Dos Santos JS, Xavier AA, Weber J, Leães FL, Junior SB, Emanuelli T (2006) Levels of polychlorinated biphenyls (PCBs) in meat and meat products from the state of Rio Grande do Sul, Brazil. Food Chem Toxicol 44(1):1-7 [PubMed: 16216403]

Curran CP, Miller KA, Dalton TP, Vorhees CV, Miller ML, Shertzer HG et al. (2006) Genetic differences in lethality of newborn mice treated in utero with coplanar versus non-coplanar hexabromobiphenyl. Toxicol Sci 89:454-464 [PubMed: 16291824]

Curran CP, Vorhees CV, Williams MT, Genter MB, Nebert DW (2011a) In utero and lactational exposure to a complex mixture of polychlorinated biphenyls: toxicity in pups dependent on the Cyp1a2. and Ahr genotypes. Toxicol Sci 119:189-208 [PubMed: 20961953]

Curran CP, Nebert DW, Genter MB, Patel KV, Schafer TL, Skelton MR, Williams MT, Vorhees CV (2011b) In utero and lactational exposure to PCBs in mice: adult offspring show altered learning and memory depending on Cyp1a2 and Ahr genotypes. Enironv Health Perspect 119(9):12861293

Curran CP, Altenhofen E, Ashworth AA, Brown A, Curran MA, Evans A, Floyd R, Fowler JP, Garber H, Hays B, Kamau-Cheggeh C, Kraemer S, Lang AL, Mynhier A, Samuels A, Strohamier C (2012) AhrdCyp1a2(-/-) mice show increased susceptibility to PCB-induced developmental neurotoxicity. Neurotoxicology 33(6):1436-1442 [PubMed: 22935098] 
Darras VM (2008) Endocrine disrupting polyhalogenated organic pollutants interfere with thyroid hormone signalling in the developing brain. Cerebellum 7(1):26-37 [PubMed: 18418666]

Denison MS, Faber SC (2017) And now for something completely different: diversity in liganddependent activation of Ah receptor responses. Curr Opin Toxicol 2:124-131 [PubMed: 28845473]

Diliberto JJ, Burgin D, Birnbaum LS (1997) Role of CYP1A2 in hepatic sequestration of dioxin: studies using CYP1A2 knock-out mice. Biochem Biophys Res Commun 236:431-433 [PubMed: 9240455]

Doull J (2003) The "Red Book" and other risk assessment milestones. Hum Ecol Risk Assess 9:1229_ 1238

Dragin N, Dalton TP, Miller ML, Shertzer HG, Nebert DW (2006) For dioxin-induced birth defects, mouse or human CYP1A2 in maternal liver protects whereas mouse CYP1A1 and CYP1B1 are inconsequential. J Biol Chem 281:18591-18600 [PubMed: 16636061]

Fauquier T, Chatonnet F, Picou F, Richard S, Fossat N, Aguilera N, Lamonerie T, Flamant F (2014) Purkinje cells and Bergmann glia are primary targets of the TRa1 thyroid hormone receptor during mouse cerebellum postnatal development. Development 141:166-175 [PubMed: 24346699]

Gauger KJ, Giera S, Sharlin DS, Bansal R, Iannacone E, Zoeller RT (2007) Polychlorinated biphenyls 105 and 118 form thyroid hormone receptor agonists after cytochrome P4501A1 activation in rat pituitary GH3 cells. Environ Health Perspect 115:1623-1630 [PubMed: 18007995]

Giera S, Bansal R, Ortiz-Toro TM, Taub DG, Zoeller RT (2011) Individual polychlorinated biphenyl (PCB) congeners produce tissue- and gene-specific effects on thyroid hormone signaling during development. Endocrinology 152(7):2909-2919 [PubMed: 21540284]

Goldey ES, Crofton KM (1998) Thyroxine replacement attenuates hypothyroxinemia, hearing loss, and motor deficits following developmental exposure to Aroclor 1254 in rats. Toxicol Sci 45(1): 94-105 [PubMed: 9848116]

Goldman SM (2014) Environmental toxins and Parkinson's disease. Annu Rev Pharmacol Toxicol 54:141-164 [PubMed: 24050700]

Gomara B, Bordajandi LR, Fernandez MA, Herrero L, Abad E, Abalos M, Rivera J, González MJ (2005) Levels and trends of polychlorinated dibenzo-p-dioxins/furans (PCDD/Fs) and dioxin-like polychlorinated biphenyls (PCBs) in Spanish commercial fish and shellfish products, 1995-2003. J Agric Food Chem 53:8406-8413 [PubMed: 16218694]

González-Franco DA, Ramírez-Amaya V, Joseph-Bravo P, Prado-Alcalá RA, Quirarte GL (2017) Differential Arc protein expression in dorsal and ventral striatum after moderate and intense inhibitory avoidance training. Neurobiol Learn Mem 40:17-26

Haijima A, Lesmana R, Shimokawa N, Amano I, Takatsuru Y, Koibuchi N (2017) Differential neurotoxic effects of in utero and lactational exposure to hydroxylated polychlorinated biphenyl (OH-PCB 106) on spontaneous locomotor activity and motor coordination in young adult male mice. J Toxicol Sci 42(4):407-416 [PubMed: 28717099]

Hamilton BA, Frankel WN, Kerrebrock AW, Hawkins TL, FitzHugh W, Kusumi K, Russell LB, Mueller KL, van Berkel V, Birren BW, Kruglyak L, Lander ES (1996) Disruption of the nuclear hormone receptor RORa in staggerer mice. Nature 379:736-739 [PubMed: 8602221]

Hatcher-Martin JM, Gearing M, Steenland K, Levey AI, Miller GW, Pennell KD (2012) Association between polychlorinated biphenyls and Parkinson's disease neuropathology. Neurotoxicology 33:1298-1304 [PubMed: 22906799]

Herrick RF, Meeker JD, Altshul L (2011) Serum PCB levels and congener profiles among teachers in PCB-containing schools: a pilot study. Environ Health 10:56 [PubMed: 21668970]

Hovander L, Linderholm L, Athanasiadou M, Athanassiadis I, Bignert A, Fängström B, Kocan A, Petrik J, Trnovec T, Bergman A (2006) Levels of PCBs and their metabolites in the serum of residents of a highly contaminated area in eastern Slovakia. Environ Sci Technol 40(12):36963703 [PubMed: 16830529]

Hu D, Hornbuckle KC (2010) Inadvertent polychlorinated biphenyls in commercial paint pigments. Environ Sci Technol 44(8):2822-2827 [PubMed: 19957996]

Jacobson JL, Jacobson SW (1997) Evidence for PCBs as neurodevelopmental toxicants in humans. Neurotoxicology 18:415-424 [PubMed: 9291491] 
Jacobson JL, Jacobson SW (2003) Prenatal exposure to polychlorinated biphenyls and attention at school age. J Pediatr 143:780-788 [PubMed: 14657828]

Kania-Korwel I, Parkin S, Robertson LW, Lehmler H-J (2004) Synthesis of polychlorinated biphenyls and their metabolites with a modified Suzuki-coupling. Chemosphere 56:735-744 [PubMed: $15251288]$

Kania-Korwel I, Hornbuckle KC, Peck A, Ludewig G, Robertson LW, Sulkowski WW, Espandiari P, Gairola CG, Lehmler H-J (2005) Congener specific tissue distribution of Aroclor 1254 and a highly chlorinated environmental PCB mixture in rats. Environ Sci Technol 39:3513-3520 [PubMed: 15954224]

Kania-Korwel I, Shaikh N, Hornbuckle KC, Robertson LW, Lehmler H-J (2007) Enantioselective disposition of PCB $136\left(2,2^{\prime}, 3,3^{\prime}, 6,6^{\prime}\right.$-hexachlorobiphenyl) in C57BL/6 mice after oral and intraperitoneal administration. Chirality 19:56-66 [PubMed: 17089340]

Kania-Korwel I, Zhao H, Norstrom K, Li X, Hornbuckle KC, Lehmler HJ (2008) Simultaneous extraction and clean-up of polychlorinated biphenyls and their metabolites from small tissue samples using pressurized liquid extraction. J Chromatogr A 1214:37-46 [PubMed: 19019378]

Koh WX, Hornbuckle KC, Marek RF, Wang K, Thorne PS (2016) Hydroxylated polychlorinated biphenyls in human sera from adolescents and their mothers living in two U.S. Midwestern communities. Chemosphere 147:389-395 [PubMed: 26774304]

Koibuchi N, Chin WW (2000) Thyroid hormone action and brain development. Trends Endocrinol Metab 11(4):123-128 [PubMed: 10754532]

Koibuchi N, Yamaoka S, Chin WW (2001) Effect of altered thyroid status on neurotrophin gene expression during postnatal development of the mouse cerebellum. Thyroid 11(3):205-210 [PubMed: 11327610]

Lambert GH, Needham LL, Turner W, Lai TJ, Patterson DG, Jr, Guo YL (2006) Induced CYP1A2 activity as a phenotypic biomarker in humans highly exposed to certain PCBs/PCDFs. Environ Sci Technol 40(19):6176-6180 [PubMed: 17051818]

Langer P, Kocan A, Tajtakova M, Petrik J, Chovancova J, Drobna B et al. (2007) Fish from industrially polluted freshwater as the main source of organochlorinated pollutants and increased frequency of thyroid disorders and dysglycemia. Chemosphere 67:S379-S385 [PubMed: 17222442]

Lee DW, Notter SA, Thiruchelvam M, Dever DP, Fitzpatrick R, Kostyniak PJ, Cory-Slechta DA, Opanashuk LA (2012) Subchronic polychlorinated biphenyl (Aroclor 1254) exposure produces oxidative damage and neuronal death of ventral midbrain dopaminergic systems. Toxicol Sci 125(2):496-508 [PubMed: 22094459]

Lehmler H-J, Robertson LW (2001) Synthesis of polychlorinated biphenyls (PCBs) using the Suzukicoupling. Chemosphere 45:137-143 [PubMed: 11572605]

Lein PJ, Yang D, Bachstetter AD, Tilson HA, Harry GJ, Mervis RF, Kodavanti PR (2007) Ontogenetic alterations in molecular and structural correlates of dendritic growth after developmental exposure to polychlorinated biphenyls. Environ Health Perspect 115(4):556-563 [PubMed: 17450224]

Lin TM, Ko K, Moore RW, Buchanan DL, Cooke PS, Peterson RE (2001) Role of the aryl hydrocarbon receptor in the development of control and 2,3,7,8-tetrachlorodibenzo-p-dioxinexposed male mice. J Toxicol Environ Health A 64(4):327-342 [PubMed: 11693491]

Lin P, Hu SW, Chang TH (2003) Correlation between gene expression of aryl hydrocarbon receptor (AhR), hydrocarbon receptor nuclear translocator (Arnt), cytochromes P4501A1 (CYP1A1) and 1B1 (CYP1B1), and inducibility of CYP1A1 and CYP1B1 in human lymphocytes. Toxicol Sci 71(1):20-26 [PubMed: 12520072]

López-Juárez A, Morales-Lázaro S, Sánchez-Sánchez R, Sunkara M, Lomelí H, Velasco I, Morris AJ, Escalante-Alcalde D (2011) Expression of LPP3 in Bergmann glia is required for proper cerebellar sphingosine-1-phosphate metabolism/signaling and development. Glia 59(4):577-589 [PubMed: 21319224]

Maervoet J, Covaci A, Schepens P, Sandau CD, Letcher R (2004) A reassessment of the nomenclature of polychlorinated biphenyl (PCB) metabolites. Environ Health Perspect 112:291-294 [PubMed: 14998742] 
Marek RF, Thorne PS, DeWall J, Hornbuckle KC (2014) Variability in PCB and OH-PCB serum levels in children and their mothers in urban and rural U.S. communities. Environ Sci Technol 48(22): 13459-13467 [PubMed: 25300024]

Marek RF, Thorne PS, Herkert NJ, Awad AM, Hornbuckle KC (2017) Airborne PCBs and OH-PCBs inside and outside urban and rural U.S. schools. Environ Sci Technol 51(14):7853-7860 [PubMed: 28656752]

Nebert DW (2017) Aryl hydrocarbon receptor (AHR): "pioneer member" of the basic-helix/loop/helix per-Arnt-sim (bHLH/PAS) family of "sensors" of foreign and endogenous signals. Prog Lipid Res 67:38-57 [PubMed: 28606467]

Nebert DW, Dalton TP (2006) The role of cytochrome P450 enzymes in endogenous signalling pathways and environmental carcinogenesis. Nat Rev Cancer 6:947-960 [PubMed: 17128211]

Nebert DW, Wikvall K, Miller WL (2013) Human cytochromes P450 in health and disease. Philos Trans R Soc Lond B Biol Sci 368(1612):20120431 [PubMed: 23297354]

Pessah IN, Cherednichenko G, Lein PJ (2010) Minding the calcium store: Ryanodine receptor activation as a convergent mechanism of PCB toxicity. Pharmacol Ther 125:260-285 [PubMed: 19931307]

Petersen MS, Halling J, Bech S, Wermuth L, Weihe P, Nielsen F et al. (2008) Impact of dietary exposure to food contaminants on the risk of Parkinson's disease. Neurotoxicology 29:584-590 [PubMed: 18455239]

Qiu CH, Miyazaki W, Iwasaki T, Londoño M, Ibhazehiebo K, Shimokawa N, Koibuchi N (2009) Retinoic Acid receptor-related orphan receptor alpha-enhanced thyroid hormone receptor-mediated transcription requires its ligand binding domain which is not, by itself, sufficient: possible direct interaction of two receptors. Thyroid 19(8):893-898 [PubMed: 19645616]

Quinn CL, Wania F, Czub G, Breivik K (2011) Investigating intergenerational differences in human PCB exposure due to variable emissions and reproductive behaviors. Environ Health Perspect 119:641-646 [PubMed: 21156396]

Ross G (2004) The public health implications of polychlorinated biphenyls (PCBs) in the environment. Ecotoxicol Environ Saf 59:275-291 [PubMed: 15388267]

Ruder AM, Hein MJ, Hopf NB, Waters MA. (2014). Mortality among 24,865 workers exposed to polychlorinated biphenyls (PCBs) in three electrical capacitor manufacturing plants: a ten-year update. Int J Hyg Environ Health 217(2-3):176-187 [PubMed: 23707056]

Sandau CD, Ayotte P, Dewailly E, Duffe J, Norstrom RJ (2000) Analysis of hydroxylated metabolites of PCBs (OH-PCBs) and other chlorinated phenolic compounds in whole blood from Canadian inuit. Environ Health Perspect 108:611-616 [PubMed: 10903613]

Schantz SL, Widholm JJ, Rice DC (2003) Effects of PCB exposure on neuropsychological function in children. Environ Health Perspect 111:357-576 [PubMed: 12611666]

Schramm H, Robertson LW, Oesch F (1985) Differential regulation of hepatic glutathione transferase and glutathione peroxidase activities in the rat. Biochem Pharmacol 34:3735-3739 [PubMed: 4052112]

Seegal RF, Brosch KO, Bush B (1986) Polychlorinated biphenyls produce regional alterations of dopamine metabolism in rat brain. Toxicol Lett 30:197-202 [PubMed: 3085294]

Seegal RF, Bush B, Brosch KO (1994) Decreases in dopamine concentrations in adult, non-human primate brain persist following removal from polychlorinated biphenyls. Toxicology 86:71-87 [PubMed: 8134924]

Seegal RF, Brosch KO, Okoniewski RJ (1997) Effects of in utero and lactational exposure of the laboratory rat to $2,4,2^{\prime}, 4^{\prime}$ - and $3,4,3^{\prime}, 4^{\prime}$-tetrachlorobiphenyl on dopamine function. Toxicol Appl Pharmacol 146:95-103 [PubMed: 9299601]

Seegal RF, Brosch KO, Okoniewski RJ (2005) Coplanar PCB congeners increase uterine weight and frontal cortical dopamine in the developing rat: implications for developmental neurotoxicity. Toxicol Sci 86:125-131 [PubMed: 15843507]

Seegal RF, Marek KL, Seibyl JP, Jennings DL, Molho ES, Higgins DS, Factor SA, Fitzgerald EF, Hills EA, Korrick SA, Wolff MS, Haase RF, Todd AC, Parsons P, McCaffrey RJ (2010) Occupational exposure to PCBs reduces striatal dopamine transporter densities only in women: a beta-CIT imaging study. Neurobiol Dis 38(2): 219-225 [PubMed: 20096358] 
Steenland K, Hein MJ, Cassinelli RT, Prince MM, Nilsen NB, Whelan EA et al. (2006)

Polychlorinated biphenyls and neurodegenerative disease mortality in an occupational cohort. Epidemiology 17:8-13 [PubMed: 16357589]

Stegman M, Curran CP, Infante SK, Kromme M, Hays B, Taylor K, Garber H, Lang A (2014) Assessing genetic susceptibility to motor function deficits following developmental exposure to polychlorinated biphenyls. Toxicol Sci Supp 138(1):457-458

Stewart P, Reihman J, Lonky E, Darvill T, Pagano J (2000) Prenatal PCB exposure and neonatal behavioral assessment scale (NBAS) performance. Neurotoxicol Teratol 22(1):21-29 [PubMed: 10642111]

Takahashi M, Negishi T, Tashior T (2008) Identification of genes mediating thyroid hormone action in the developing mouse cerebellum. J Neurochem 104:640-652 [PubMed: 18005342]

Takeuchi S, Shiraishi F, Kitamura S, Kuroki H, Jin K, Kojima H (2011) Characterization of steroid hormone receptor activities in 100 hydroxylated polychlorinated biphenyls, including congeners identified in humans. Toxicology 289:112-121 [PubMed: 21843587]

Ulbrich B, Stahlmann R (2004) Developmental toxicity of polychlorinated biphenyls (PCBs): a systematic review of experimental data. Arch Toxicol 78:252-268 [PubMed: 15064922]

United Nations Environmental Program (UNEP) (2001). Stockholm convention on persistent organic pollutants. http://chm.pops.int/TheConvention/Overview/tabid/3351/Default.aspx

van den Berg M, Birnbaum LS, Denison M, De VM, Farland W, Feeley M et al. (2006) The 2005 World Health Organization reevaluation of human and Mammalian toxic equivalency factors for dioxins and dioxin-like compounds. Toxicol Sci 93:223-241 [PubMed: 16829543]

Van Dine SE, Siu NY, Toia A, Cuoco JA, Betz AJ, Bolivar VJ, Torres G, Ramos RL (2015) Spontaneous malformations of the cerebellar vermis: prevalence, inheritance, and relationship to lobule/fissure organization in the C57BL/6 lineage. Neuroscience 310:242-251 [PubMed: 26383253]

Van den Berg BM, Birnbaum L, Bosveld AT, Brunstrom B, Cook P, Feeley M et al. (1998) Toxic equivalency factors (TEFs) for PCBs, PCDDs, PCDFs for humans and wildlife. Environ Health Perspect 106:775-792 [PubMed: 9831538]

van den Hurk P, Kubiczak GA, Lehmler HJ, James MO (2002) Hydroxylated polychlorinated biphenyls as inhibitors of the sulfation and glucuronidation of 3-hydroxy-benzo[a]pyrene. Environ Health Perspect 110:343-348 [PubMed: 11940451]

Vanden Heuvel JP, Clark GC, Thompson CL, McCoy Z, Miller CR, Lucier GW et al. (1993) CYP1A1 mRNA levels as a human exposure biomarker: use of quantitative polymerase chain reaction to measure CYP1A1 expression in human peripheral blood lymphocytes. Carcinogenesis 14:20032006 [PubMed: 8222045]

Vreugdenhil HJ, Lanting CI, Mulder PG, Boersma ER, Weisglas-Kuperus N (2002) Effects of prenatal PCB and dioxin background exposure on cognitive and motor abilities in Dutch children at school age. J Pediatr 140:48-56 [PubMed: 11815763]

Wadzinski TL, Geromini K, McKinley Brewer J, Bansal R, Abdelouahab N, Langlois MF, Takser L, Zoeller RT (2014) Endocrine disruption in human placenta: expression of the dioxin-inducible enzyme, CYP1A1, is correlated with that of thyroid hormone-regulated genes. J Clin Endocrinol Metab 99(12):E2735-E2743 [PubMed: 25299844]

Weisskopf MG, Knekt P, O’Reilly EJ, Lyytinen J, Reunanen A, Laden F, Altshul L, Ascherio A (2012) Polychlorinated biphenyls in prospectively collected serum and Parkinson's disease risk. Mov Disord 27(13):1659-1665 [PubMed: 23044514]

Wilhelm M, Wittsiepe J, Lemm F, Ranft U, Krämer U, Fürst P, Röseler SC, Greshake M, Imöhl M, Eberwein G, Rauchfuss K, Kraft M, Winneke G (2008) The Duisburg birth cohort study: influence of the prenatal exposure to PCDD/Fs and dioxin-like PCBs on thyroid hormone status in newborns and neurodevelopment of infants until the age of 24 months. Mutat Res 659(1-2):83-92 [PubMed: 18093869]

Zoeller RT, Rovett J (2004) Timing of thyroid hormone action in the developing brain: clinical observations and experimental findings. J Neuroendocrinol 16:809-818 [PubMed: 15500540] 


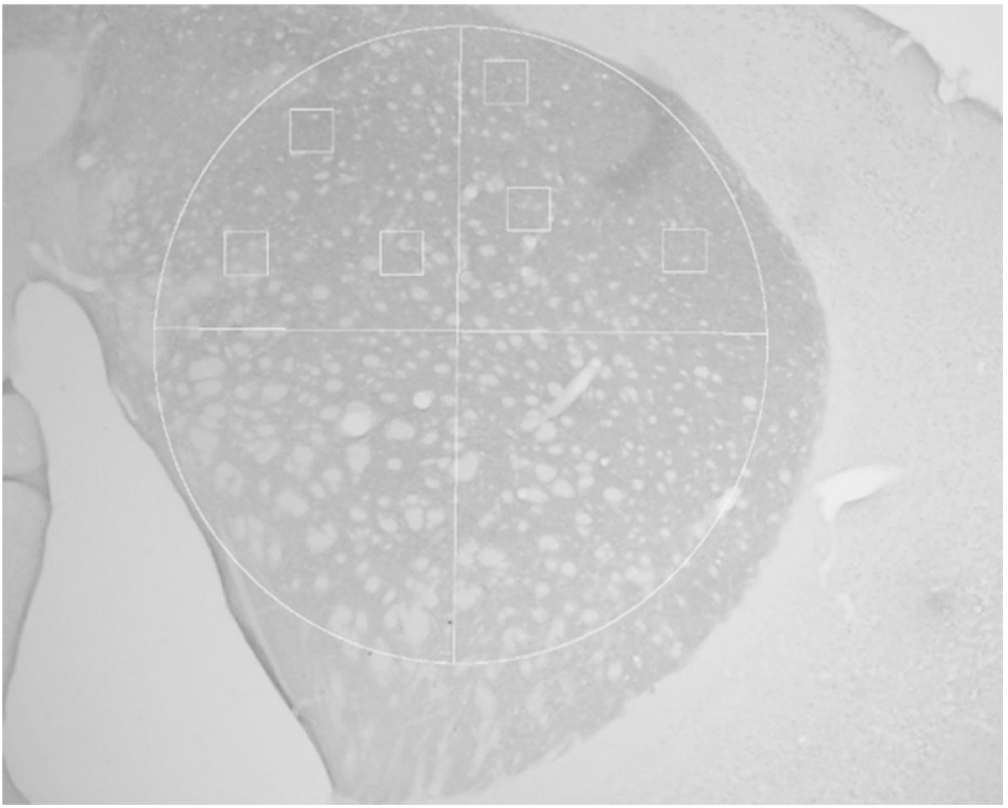

Fig. 1.

Sampling scheme for optical density measurements in the dorsal striatum. Modified from González-Franco et al. (2017) 

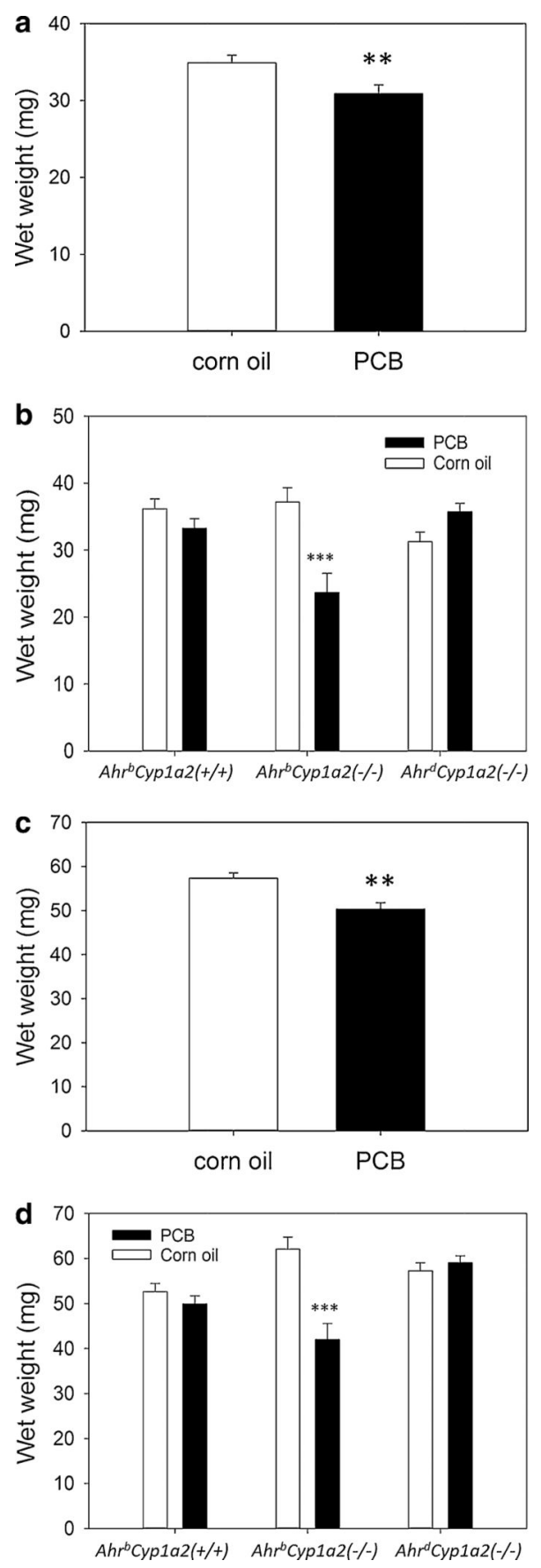

Fig. 2.

a, b Spleen wet weights. There was a main effect of treatment $\mathbf{w i t h}$ PCB-exposed pups having significantly lower spleen weights at P14 compared to vehicle-treated controls. There was also a significant gene $\times$ treatment interaction with PCB-treated $A h r^{b} C y p 1 a 2(-/-)$ knockout mice having significantly lower spleen weights than all other groups. LS means \pm SEM, $* * P<0.01 ; * * * P<0.001, \mathbf{c}, \mathbf{d}$ Thymus wet weights. There was a main effect of treatment with PCB-exposed pups having significantly lower thymus weights at P14 compared to vehicle-treated controls. There was no gene $\times$ treatment interaction, although 
$A h r^{b}$ Cypla2(-/-) knockout mice showed the greatest reduction compared to controls. LS means \pm SEM, $* * * P<0.001$ 

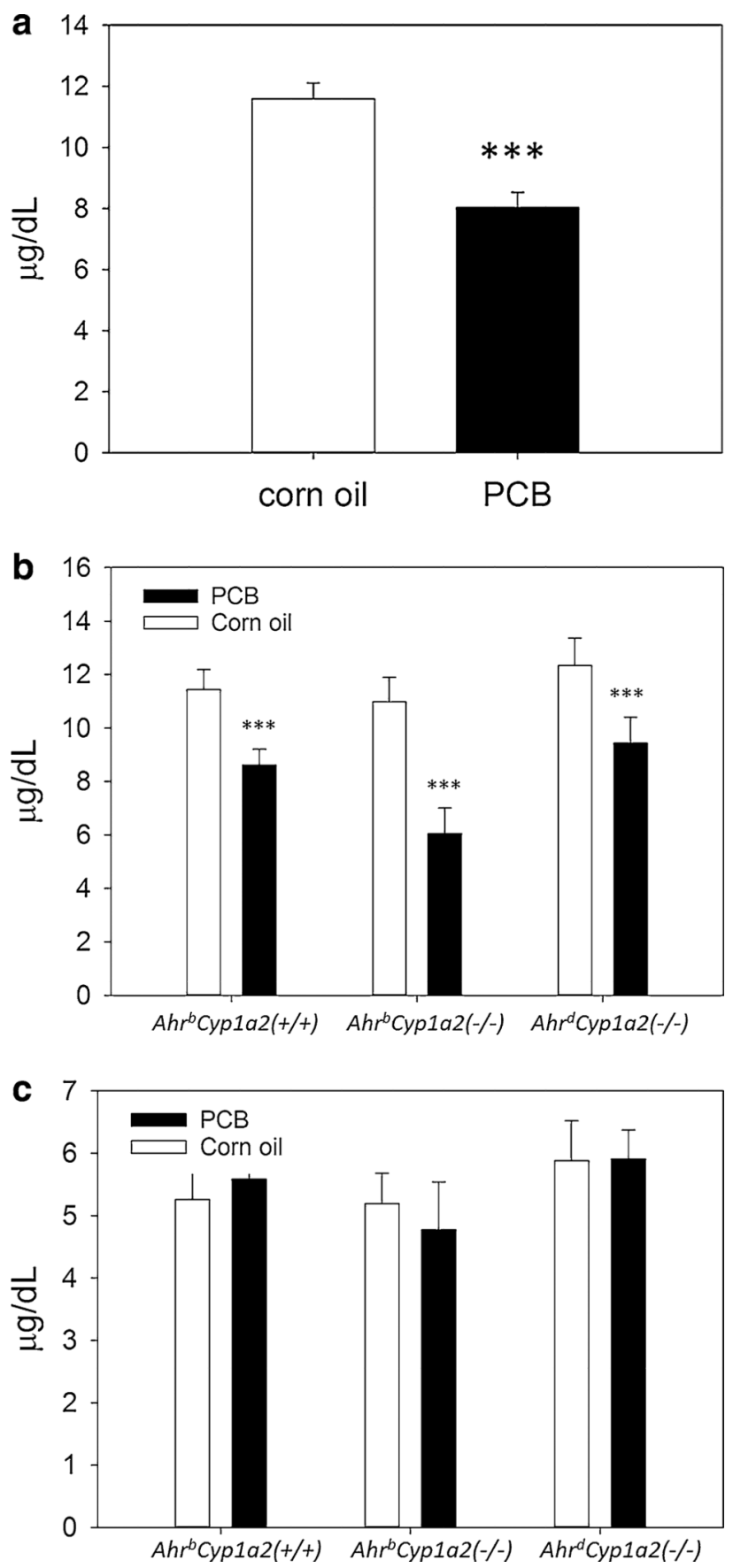

Fig. 3.

a, b Thyroxine levels in neonates. There was a main effect of treatment with PCB-exposed pups having significantly lower circulating thyroxine at P14 compared to vehicle-treated controls. There was no gene $\times$ treatment interaction, although $A h r^{b}$ Cyp1a2(-/-) knockout mice showed the greatest reduction compared to controls. LS means \pm SEM, $* * * P<0.001$, c Thyroxine levels in adults. Free thyroxine levels returned to normal in adult mice tested at 4 months of age with no significant differences by genotype or treatment. LS means \pm SEM, $P$ $>0.05$ 


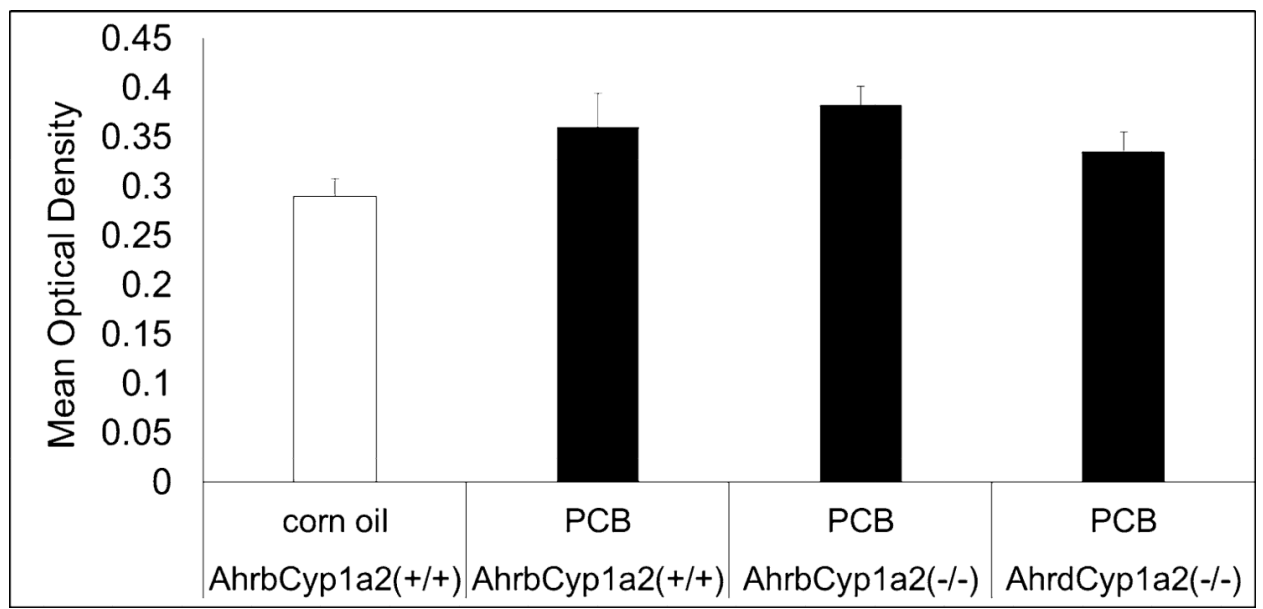

Fig. 4.

Optical density of dorsal striatum. There were no significant differences in the mean optical density recorded following immunostaining for tyrosine hydroxylase in the dorsal striatum. LS means \pm SEM, $P>0.05$ 


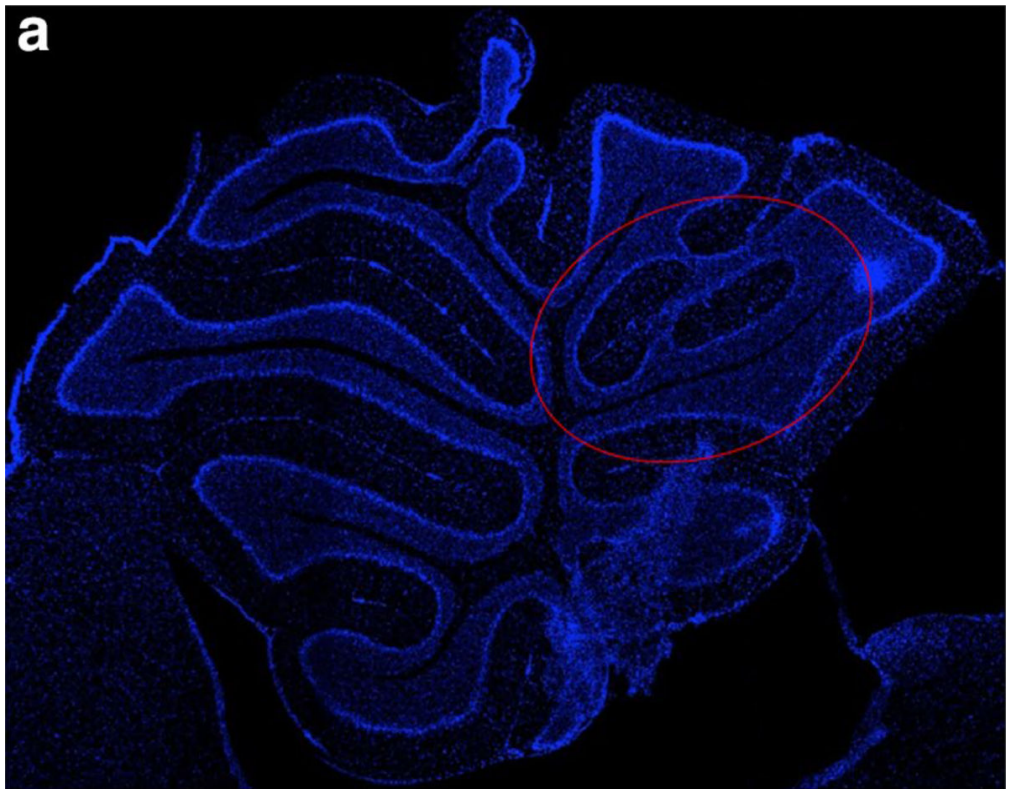

b

Fig. 5.

a, b DAPI staining of cerebellum. Representative sections from a PCB-treated $A h r^{b} C_{y p 1 a 2}(-/)$ mouse (a) compared to a corn oil-treated control $A h r^{b}{ }_{\text {Cypla2 }}(+/+)$ mouse (b) The region highlighated in red shows the foliation defect. (Color figure online) 

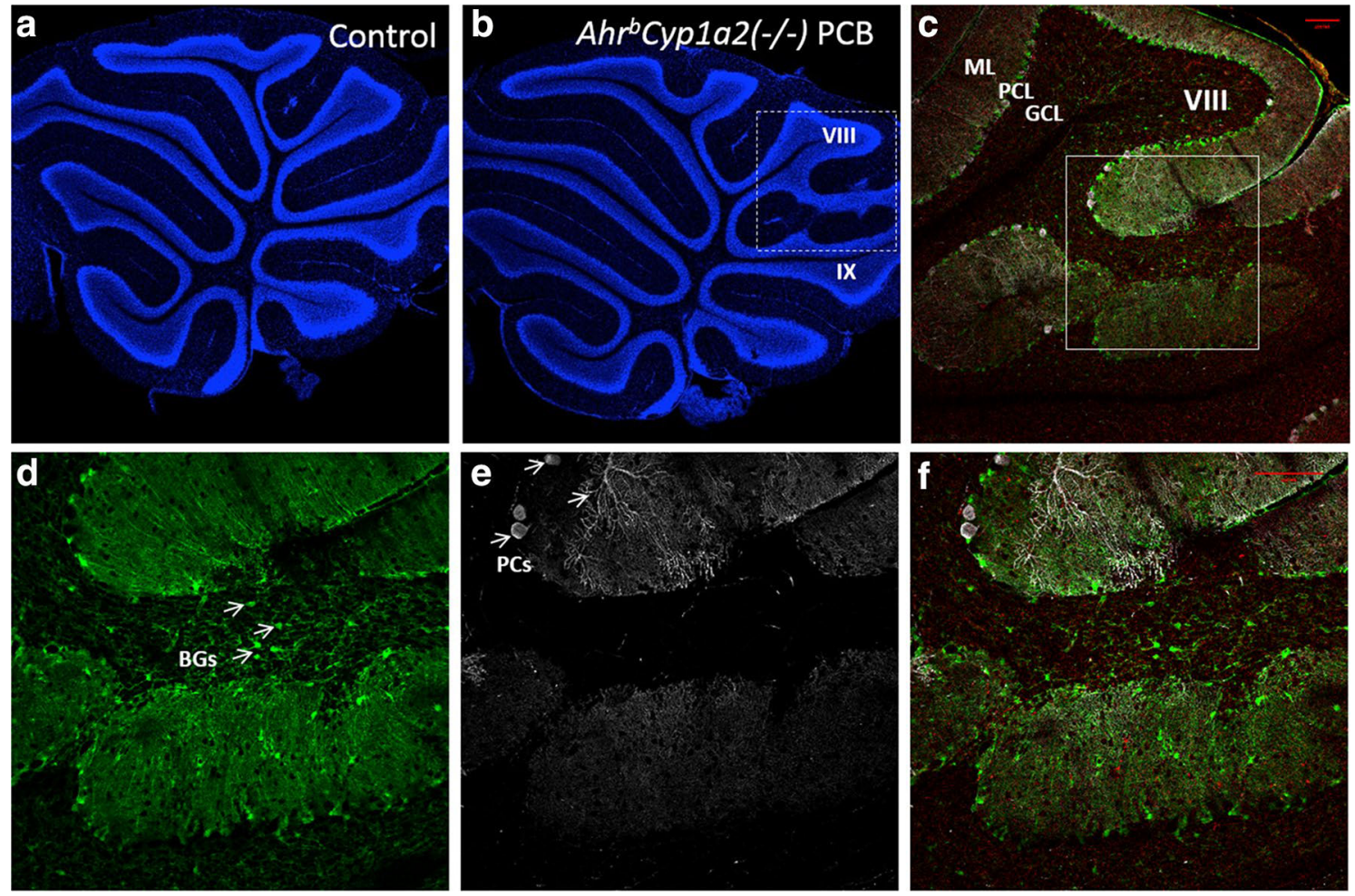

Fig. 6.

a-f Defects in lamination pattern in folia VIII-IX. a, b Representative image of a knockoutcontrol mouse (a) and knockout-treated with PCB (b) stained with DAPI. c Zoom of the dashed area in $\mathbf{b}$, showing the aberrant lamination between folias VIII and IX. Note the continuity of the GCL. $\mathbf{d}-\mathbf{f}$ Zoom of the square in $\mathbf{c}$ showing the absence of Chat + Purkinje cells (PCs, white) and the invasion of BLBP + Bergmann glial cells (BGs, green) in the folia VIII of treated KO mice. $M L$ molecular layer, $P C L$ purkinje cell layer, $G C L$ granule cell layer. Scale bar $100 \mu \mathrm{m}$. (Color figure online) 


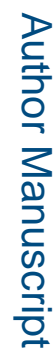

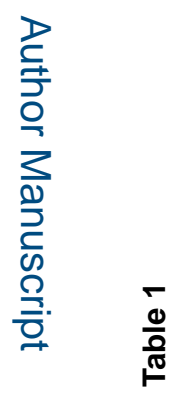

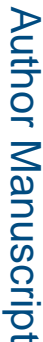

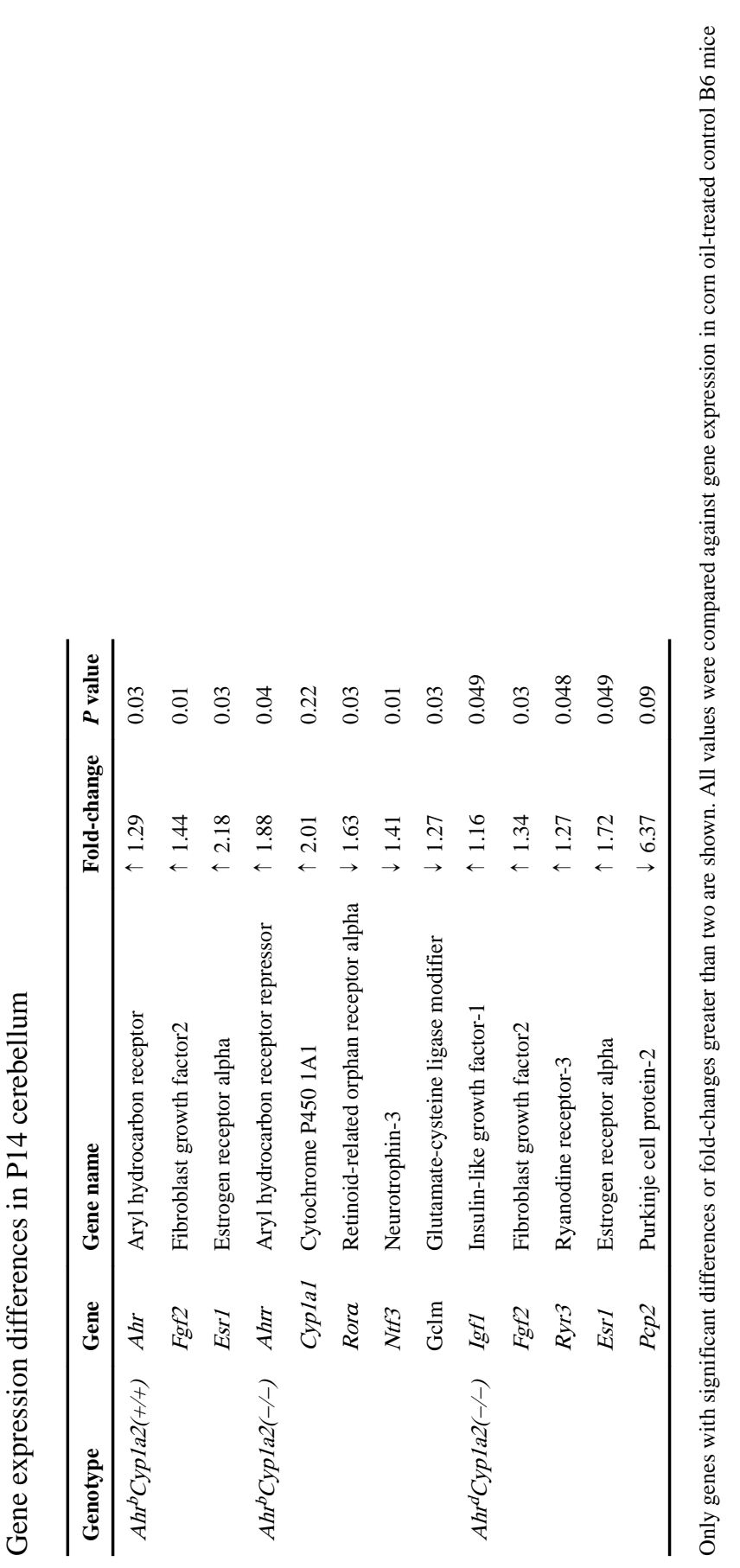

Mamm Genome. Author manuscript; available in PMC 2019 March 20. 


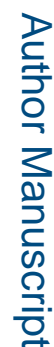

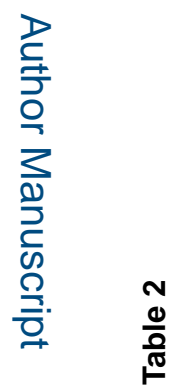



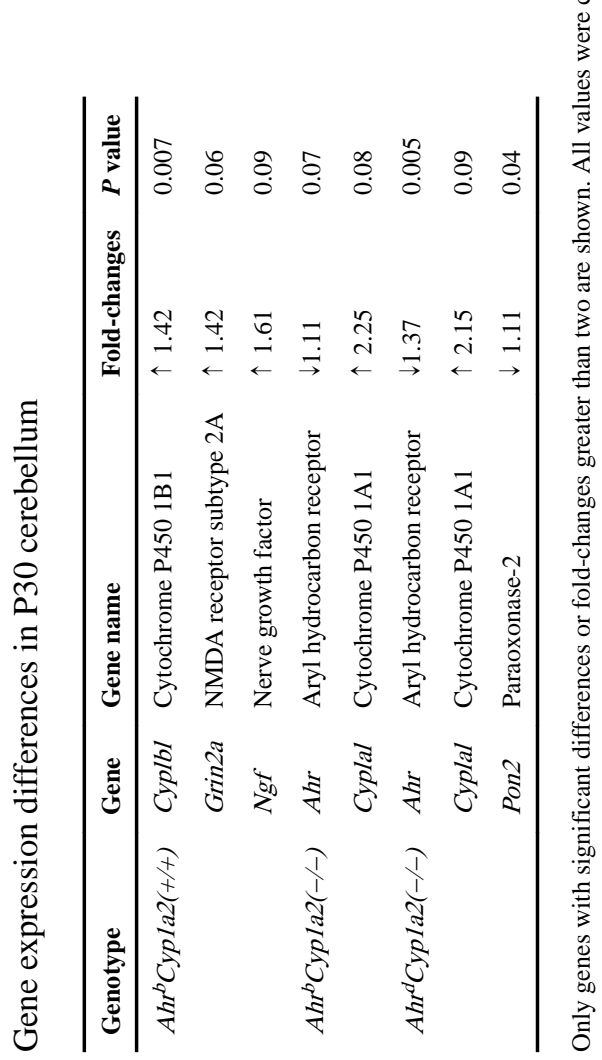




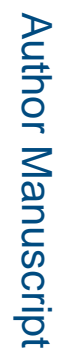

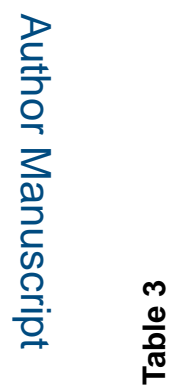

을

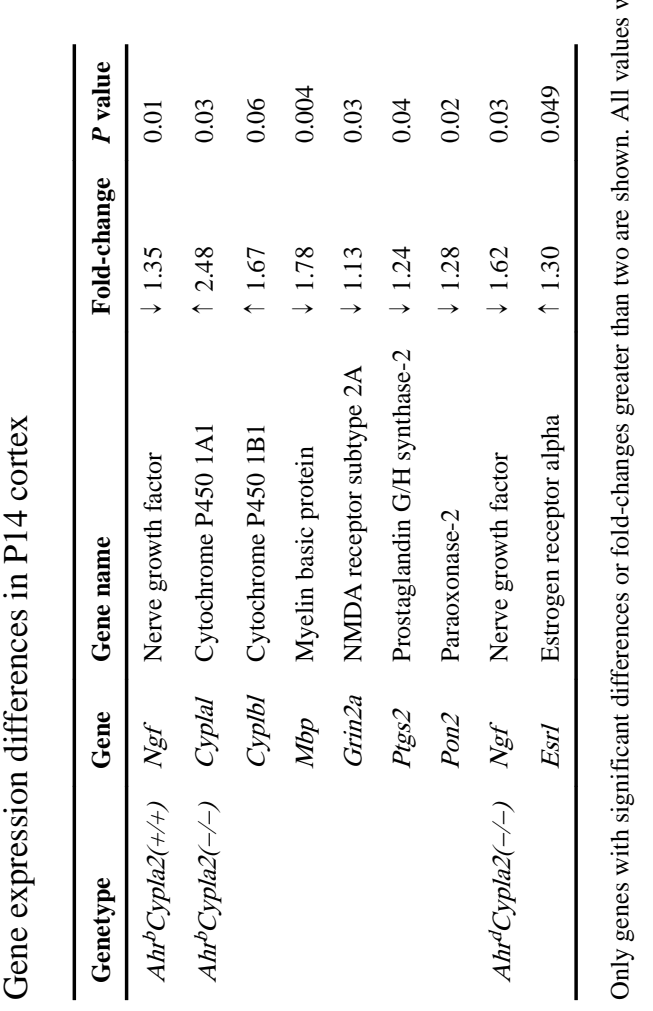

Mamm Genome. Author manuscript; available in PMC 2019 March 20. 


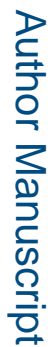

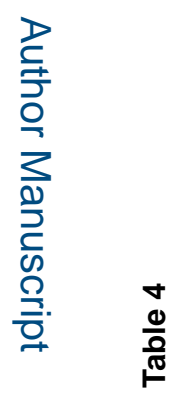

롤

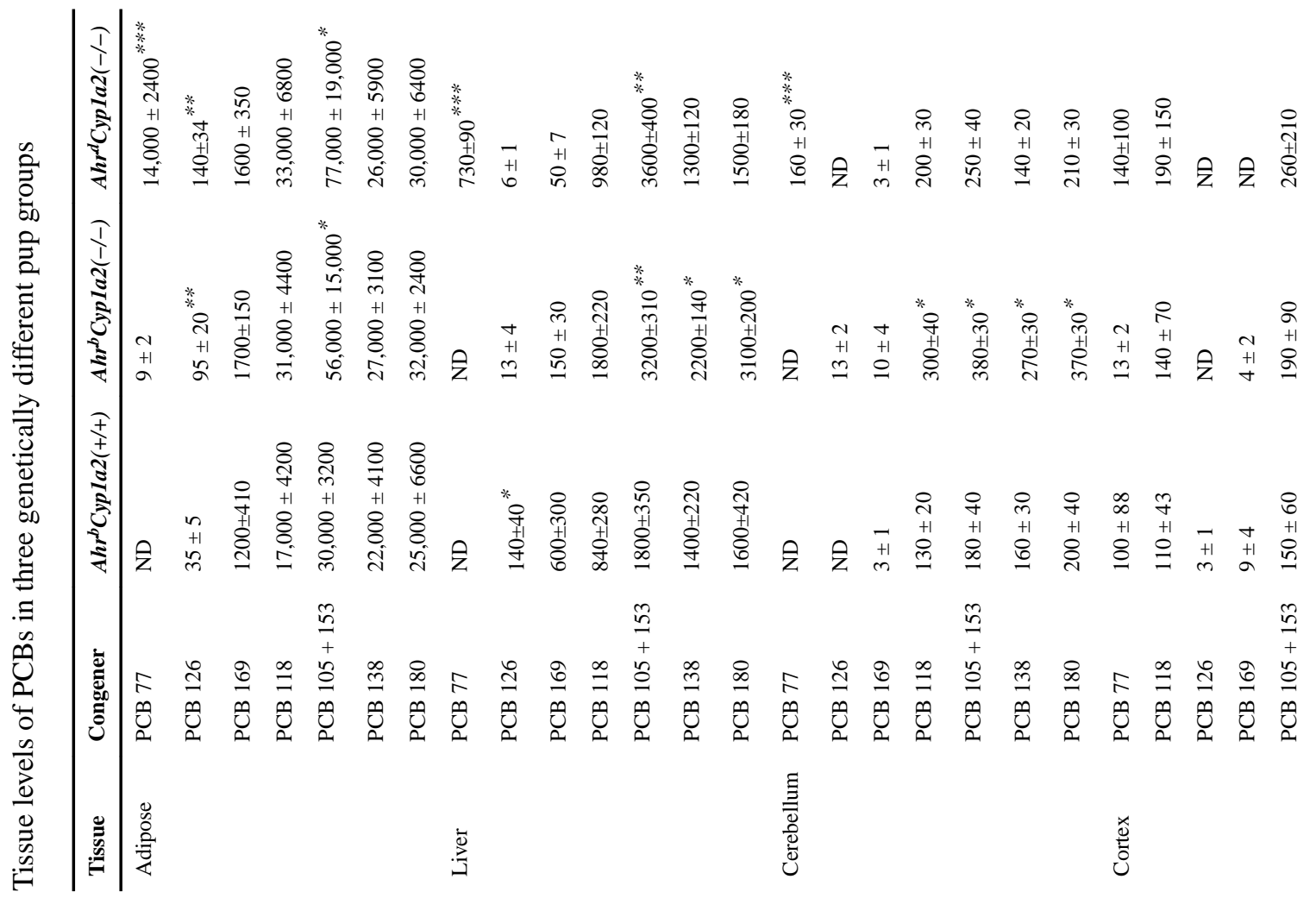

Mamm Genome. Author manuscript; available in PMC 2019 March 20. 
Klinefelter et al.

Page 30

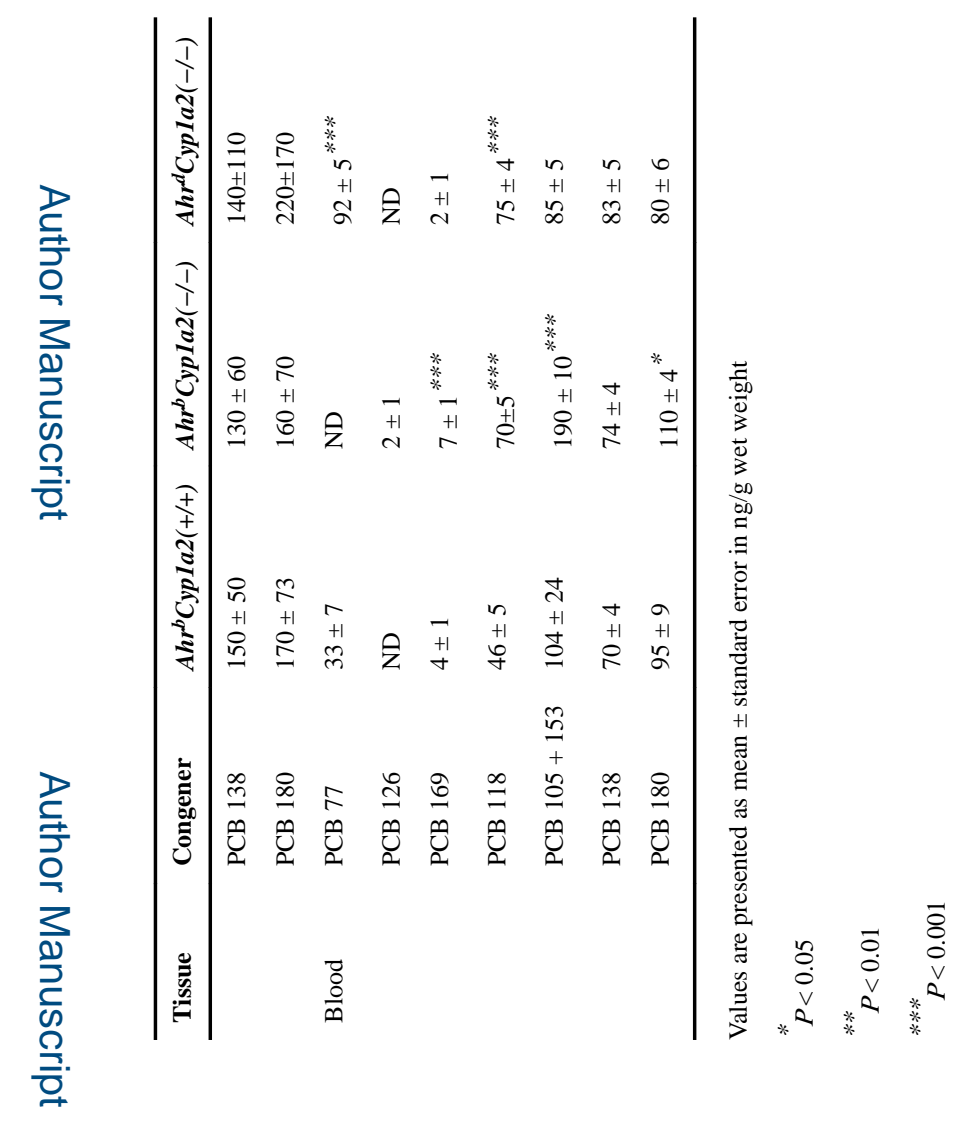

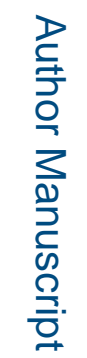

로을

Mamm Genome. Author manuscript; available in PMC 2019 March 20. 


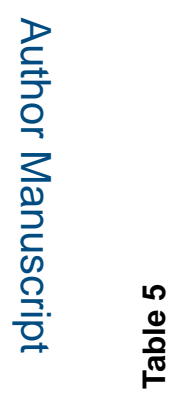

产

로을

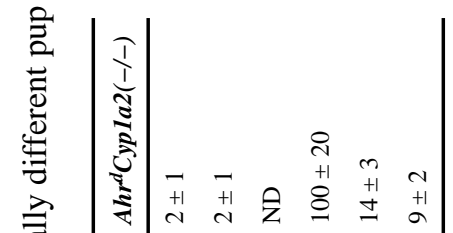

롤

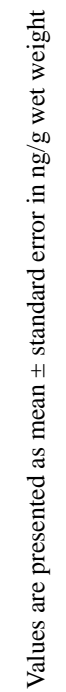

